Check for updates

Cite this: RSC Adv., 2019, 9, 16929

Received 18th February 2019 Accepted 8th May 2019

DOI: 10.1039/c9ra01253b

rsc.li/rsc-advances

\section{Kitazin-pea interaction: understanding the fungicide induced nodule alteration, cytotoxicity, oxidative damage and toxicity alleviation by Rhizobium leguminosarum}

\begin{abstract}
Mohammad Shahid, (D)*a Mohammad Saghir Khan ${ }^{a}$ and Murugan Kumar ${ }^{b}$
Realizing the severity of fungicidal toxicity to legumes and importance of fungicide tolerant rhizobia in legume production, kitazin tolerant $\left(2400 \mu \mathrm{g} \mathrm{mL}{ }^{-1}\right)$ strain RP1 was recovered from pea nodules and was identified as Rhizobium leguminosarum (accession no. KY940047). R. leguminosarum produced indole acetic acid $\left(80.5 \pm 2.5 \mathrm{~mL}^{-1}\right)$, siderophores: salicylic acid $\left(54 \pm 7.3 \mu \mathrm{g} \mathrm{mL} \mathrm{m}^{-1}\right)$ and 2,3-dihydoxybenzoic acid $\left(31.9 \pm 2.7 \mu \mathrm{g} \mathrm{mL}^{-1}\right.$ ), $\alpha$-ketobutyrate $(51 \pm 3.2$ per $\mathrm{mg}$ per protein per hour), solubilized insoluble phosphate $\left(29.5 \pm 1.8 \mu \mathrm{g} \mathrm{mL}^{-1}\right)$ and secreted $29.5+2.6 \mu \mathrm{g} \mathrm{mL}^{-1}$ exopolysaccharides, which, however, decreased consistently with gradually increasing kitazin concentrations. Beyond the tolerance level, kitazin caused structural damage and altered membrane integrity of RP1, as revealed under scanning (SEM) and confocal (CLSM) electron microscopy. Phytotoxicity of kitazin to peas was obvious under both in vitro and in vivo conditions. A significant reduction of 23, 68, 57 and 50\% in germination, seedling vigor index, plumule length and radicle length was found at $2 \times$ kitazin compared to the control. Cellular damage and cytotoxicity induced by kitazin in membrane altered root cells was detected with acridine orange/propidium iodide (AO/PI) and Evans blue dye. A maximum increase of 1.72, 5.2, 9.3 and 1.72, 5.2, 9.3-fold in red and blue fluorescence was quantified at $1 \times, 2 \times$, and $3 \times$ doses of kitazin, respectively. In contrast, application of $R$. leguminosarum RP1 alleviated toxicity and enhanced the length of plant organs, dry biomass, symbiotic attributes, photosynthetic pigments, nutrient uptake and grain features of peas comparatively uninoculated and fungicide-treated plants. Additionally, strain RP1 expressively reduced the antioxidant enzymes peroxidase, ascorbate peroxidase, guaiacol peroxidase, catalase and malondialdehyde contents by $10,2.2,11,20$ and $4 \%$ compared to stressed plants raised at $192 \mu \mathrm{g} \mathrm{kg}{ }^{-1}$ soil. Moreover, a decline of 19, 21 and $20 \%$ in proline content extracted from roots, shoots and grains, respectively was recorded for $R$. leguminosarum inoculated pea plants grown with $96 \mu \mathrm{g} \mathrm{kg}^{-1}$ kitazin. Also, the SEM and CLSM of roots revealed the bacterial colonization. In conclusion, $R$. leguminosarum tolerated a higher level of kitazin, secreted plant growth promoting (PGP) bioactive molecules even under fungicide stress and significantly increased the performance of peas while reducing the levels of proline and antioxidant enzymes. So, it can safely be suggested to legume growers that RP1 strain could inexpensively be explored as an efficient biofertilizer for enhancing the production of legumes especially peas while growing even under fungicide (kitazin) enriched soils.
\end{abstract}

\section{Introduction}

Due to their high nutritive value, legumes are considered important food crops for human beings and have habitually been cultivated around the world since primeval times. ${ }^{1}$ But, fungal diseases cause huge losses to legume production globally. To overcome such losses, legume growers adopt common

${ }^{a}$ Department of Agricultural Microbiology, Faculty of Agricultural Sciences, Aligarh Muslim University, Aligarh-202002, Uttar Pradesh, India. E-mail: shahidfaiz5@ gmail.com; Tel: +91-8090939511

${ }^{b}$ Genomics-II, ICAR-NBAIM (National Bureau of Agriculturally Important Microorganisms), Kushmaur, Mau-275103, Uttar Pradesh, India and general practices such as pre-sowing application of fungicides. The irregular and injudicious application of such plant protectants has, however, been found harmful to microbial diversity, soil fertility and legume production. ${ }^{2}$

Numerous literature reports on the toxic and harmful action of synthetic fungicides on soil properties and legume crops are available. Among them are a destruction of soil fecundity ${ }^{3}$ that leads to losses in growth, symbiosis and yield. ${ }^{4}$ Some fungicides obliterate nodule formation, affect biological nitrogen fixation (BNF), decrease the formation of photosynthetic and carotenoid pigments and disturb the whole physiological machinery of plant by inhibiting electron transport systems (ETS) of 
chloroplasts. ${ }^{5}$ Additionally, fungicides induced toxicity to plants also generates oxidative stress and leads to accumulation of reactive oxygen species (ROS). The ROS so deposited inside plant tissues in turn disrupt membrane integrity leading eventually to the leakage of electrolytes outside the cell. And hence, continued leakage of essential ions from interior to the exterior environment ultimately results into death of plants. Kitazin is a broad-spectrum systemic fungicide which belongs to organophosphorus family and is used widely in agronomic practices to combat phytopathogenic diseases. However, irreversible toxic action of fungicides against soil microflora, emergence of fungicide resistance among pathogens and environmental persistence $^{6}$ warrants need to minimize risks associated with fungicides. In this regard, several fungicide tolerant nodule bacteria such as Rhizobium sp., B. japonicum ${ }^{7}$ and Bacillus sp. ${ }^{8}$ possessing multiple PGP activities have been found to augment the growth of various legume crops. ${ }^{9-11}$

Pea (Pisum sativum) forms a strong and unambiguous symbiotic relationship with its rhizobial microsymbiont, $R$. leguminosarum. Also, this microsymbionts reduce the toxicity of pesticides by degrading and converting them into non-toxic forms. ${ }^{12}$ Apart from these, rhizobia in general, are also known to accelerate growth of legumes by other mechanisms such as release and supply of phytohormones, ${ }^{13}$ management of pathogens by secreting low molecular weight iron chelating compounds, siderophores, ${ }^{\mathbf{1 4}}$ producing enzyme (ACC deaminase) that controls ethylene stress by catalysing ACC into $\alpha$ ketobutyrate and ammonia ${ }^{15}$ and by solubilizing insoluble $\mathrm{P}^{\mathbf{1 6}}$ These versatile properties of rhizobia have prompted legume growers to apply them as microbial fertilizer in legume cultivation strategies. ${ }^{\mathbf{1 7 , 1 8}}$

Nevertheless, despite widespread application, inclusive data converging kitazin impact on oxidative stress, cytotoxicity, anatomical and structural morphology of legumes specifically on peas have completely been missing. And hence, present investigation was designed to - (i) identify and characterize the fungicide-tolerant rhizobia with multiple PGP activities (ii) evaluate the impact of kitazin on active biomolecules of rhizobia (iii) assess the impact of kitazin on germination efficiency, root tip morphology, oxidative stress and cellular death in pea roots under in vitro bio-assays (iv) evaluate the bioremediation potential of plant growth promoting $R$. leguminosarum strain RP1 on bio-chemical characteristics of pea plants grown in soils treated with kitazin and (v) assess the antioxidant response and proline level in inoculated plants grown under fungicide stress.

\section{Materials and methods}

\subsection{Physico-chemical properties and GC-MS analysis of rhizosphere soil}

Soil samples collected from rhizosphere of pea grown at experimental fields of Faculty of Agricultural Sciences, Aligarh Muslim University, Aligarh $\left(27^{\circ} 53^{\prime} \mathrm{N} 78^{\circ} 05^{\prime} \mathrm{E} 27.88^{\circ} \mathrm{N} 78.08^{\circ} \mathrm{E}\right)$, Uttar Pradesh, India were processed and analysed for different physicochemical properties using standard and widely used methods (Table 1). Further, pesticides in soils was detected by GC-MS (Fig. 1).
Table 1 Physico chemical analysis of rhizosphere soil

\begin{tabular}{ll}
\hline Parameters & Values \\
\hline Soil pH & 8.6 \\
$\mathrm{EC}\left(\mathrm{mv} \mathrm{cm}{ }^{-2}\right)$ & 0.99 \\
OC $(\%)$ & 0.58 \\
Available N $\left(\mathrm{kg} \mathrm{ha}^{-1}\right)$ & - \\
Available P $\left(\mathrm{kg} \mathrm{ha}^{-1}\right)$ & 20.25 \\
Available $\mathrm{K}\left(\mathrm{kg} \mathrm{ha}^{-1}\right)$ & 23.04 \\
$\mathrm{~S}(\mathrm{ppm})$ & - \\
Micronutrients $(\mathrm{ppm})$ & - \\
$\mathrm{Zn}$ & 1.30 \\
$\mathrm{~B}$ & - \\
Fe & 9.6 \\
Mn & 4.05 \\
Cu & 0.43 \\
Water holding capacity (mL per g per soil) & 0.65 \\
\end{tabular}

\subsection{Isolation and biochemical characterization of bacterial} isolate

Rhizobium isolates were recovered from pea nodules using yeast extract mannitol (YEM) medium ( $\mathrm{g} \mathrm{L}^{-1}$ : mannitol 10; $\mathrm{K}_{2} \mathrm{HPO}_{4}$ $0.5 ; \mathrm{MgSO}_{4} \cdot 7 \mathrm{H}_{2} \mathrm{O} 0.2 ; \mathrm{NaCl} 0.1$; yeast extract $1 ; \mathrm{CaCO}_{3} 1 ; \mathrm{pH}$ 6.5). Further, bacterial isolates were morphologically characterized and identified by various biochemical tests. ${ }^{19}$

\subsection{Fungicide tolerance, 16S rRNA based identification and phylogenetic tree construction}

Rhizobial strains were further exposed to varying concentration of kitazin [(CAS no. a.i $=48 \%$ EC, chemical family $=$ organophosphate, molecular weight $\left(\mathrm{g} \mathrm{mol}^{-1}\right)=280, \mathrm{MP}=22.5-23.8$ $\left.{ }^{\circ} \mathrm{C}\right)$ ] to select fungicide tolerant rhizobia. Minimal agar plates were amended with increasing concentrations $(0-3200 \mu \mathrm{g}$ $\left.\mathrm{mL}^{-1}\right)$ of kitazin and overnight grown rhizobial strains were spot (10 $\mu \mathrm{L}$ inoculum) inoculated. Plates were incubated at $28 \pm$ $2{ }^{\circ} \mathrm{C}$ for $48 \mathrm{~h}$ and colonies surviving at highest concentration of kitazin were picked and designated as fungicide tolerant rhizobial strains (FTRS). Of the total of 40 rhizobial strains, strain RP1 exhibiting highest tolerance to kitazin was chosen for further studies. For identification of strain RP1, 16S rDNA partial gene sequence analysis was done using universal primers 785F (5'-GGATTAGATACCCTGGTA-3') and 907R (5'CCGTCAATTCMTTTRAGTTT- $3^{\prime}$ ). The nucleotide sequence data obtained from Macrogen was deposited in GenBank sequence database. The BLASTn program available online was employed to find similar sequences with known taxonomic information accessible from the databank accessible at NCBI website (http:// www.ncbi.nlm.nih.gov/BLAST) to precisely recognize the bacterial strain RP1. Sequence was aligned using bootstrapped neighbour-joining method and a phylogenetic tree was constructed using MEGA6.0 software.

\subsection{In vitro bioassays for plant growth promoting (PGP) activities under kitazin stress}

2.4.1 Production of phytohormones, cyanogenic compounds and ammonia. Indole-3-acetic acid (IAA) synthesized by $R$. leguminosarum RP1 strain was quantified 


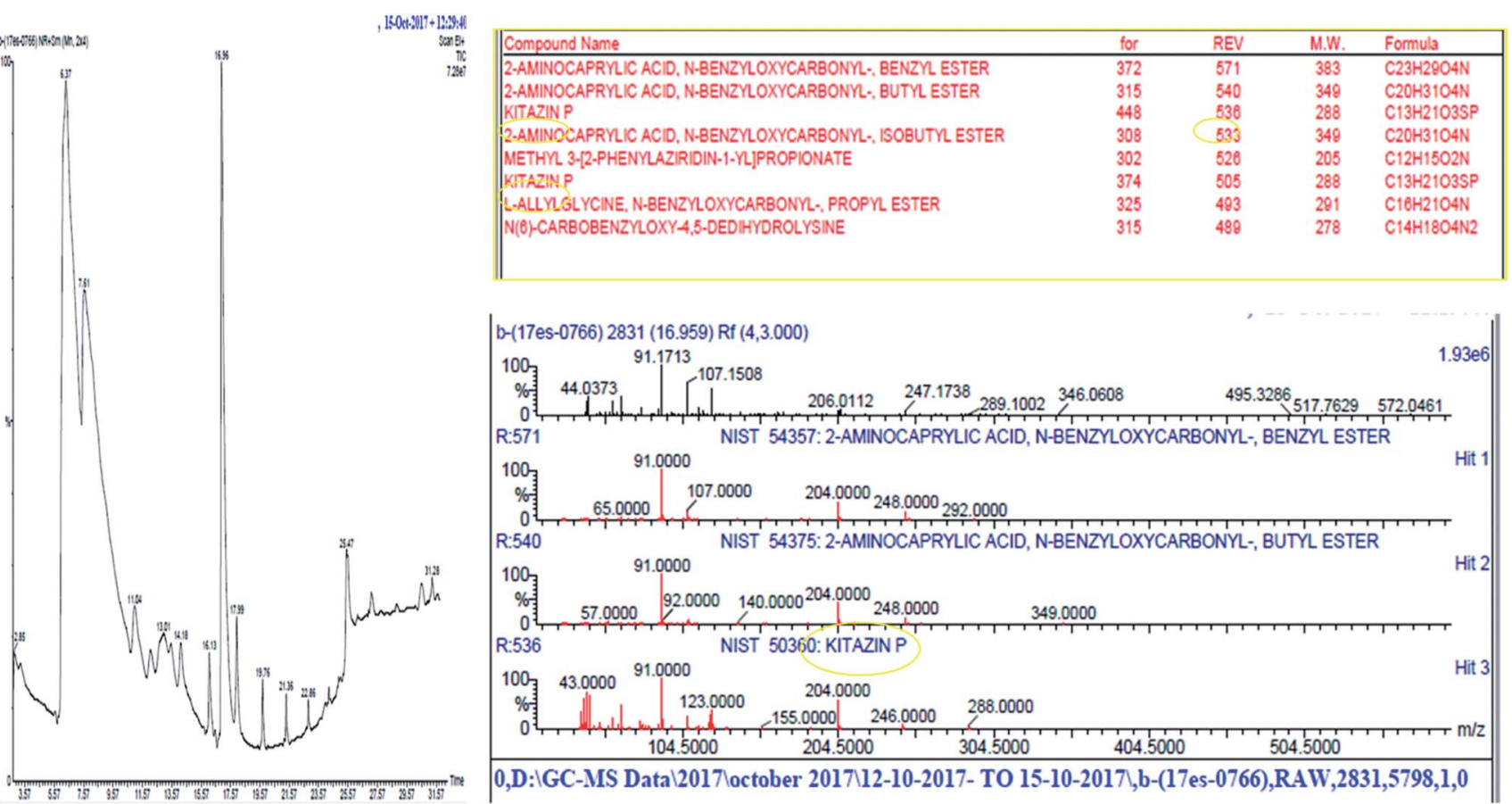

Fig. 1 GC-MS analysis of pea rhizosphere soil depicting the presence of kitazin fungicide.

spectrophotometrically by modified method of Brick et $a .^{20}$ using LB-medium containing 0 (control), normal $(1 \times)$, double $(2 \times)$ and three times $(3 \times)$ more of normal rates of kitazin. The normal concentration of kitazin used throughout the experiment was $600 \mu \mathrm{g} \mathrm{mL}^{-1}$. For HCN production, $R$. leguminosarum RP1 strain was inoculated on an HCN induction medium $\left(\mathrm{g} \mathrm{L}^{-1}\right.$ : tryptic soy broth 30 ; glycine 4.4 and agar 15 ) supplemented with $0,1 \times, 2 \times$ and $3 \times$ concentrations of kitazin and incubated at 28 $\pm 2{ }^{\circ} \mathrm{C}$ for four days. A disk of Whatman filter paper No. 1 soaked in $0.5 \%$ picric acid and $2 \% \mathrm{Na}_{2} \mathrm{CO}_{3}$ was placed under the lid of Petri plates and sealed with parafilm. After four days of incubation at $28 \pm 2{ }^{\circ} \mathrm{C}$, an orange brown colour of paper confirmed HCN production. ${ }^{21}$ The ammonia $\left(\mathrm{NH}_{3}\right)$ production by $R$. leguminosarum RP1 strain in presence of kitazin was detected as suggested by Dye. ${ }^{22}$

2.4.2 Tri calcium $P$ solubilization, siderophore production and ACC deaminase activity. The phosphate solubilization activity (PSA) was quantitatively estimated using liquid Pikovskaya medium amended with $0,1 \times, 2 \times$ and $3 \times$ concentration of kitazin. The amount of solubilized $\mathrm{P}$ was evaluated by chlorostannous reduced molybdophosphoric acid blue method ${ }^{23}$ Secretion of siderophores by the $R$. leguminosarum strain RP1 was detected qualitatively by $\mathrm{FeCl}_{3}$ test and by Chrome Azurol S (CAS) method ${ }^{24}$ using three concentrations of kitazin, added to CAS agar plates. Siderophore secreted by strain RP1 was quantitatively assayed by growing bacterial culture in Modi medium amended with three concentrations of kitazin for five days and catechol-type phenolates was determined $^{25}$ at $560 \mathrm{~nm}$ for salicylates (SA) and at $700 \mathrm{~nm}$ 2,3-dihydroxy benzoic acid (DHBA). ACC deaminase producing ability of $R$. leguminosarum strain RP1 was qualitatively assayed by Dworkin and Foster medium. ${ }^{26}$ Mesorhizobium LMS-1 having
pR-KACC plasmid was used as a positive control. ${ }^{27}$ Additionally, quantity of $\alpha$-ketobutyrate was detected as described by Penrose and Glick. ${ }^{28}$

\subsection{Growth kinetics of RP1 strain under kitazin stress}

Growth kinetics of $R$. leguminosarum was determined by the method of Ahmed et al. ${ }^{29}$ For this, $0.1 \mathrm{~mL}\left(10^{8}\right.$ cells per $\left.\mathrm{mL}\right)$ of bacterial culture was inoculated into $50 \mathrm{~mL}$ mineral salt medium (MSM) without (0) and with normal $(1 \times)$, double $(2 \times)$ and three times $(3 \times)$ more of normal rate of kitazin. The normal rate of kitazin used here was $600 \mu \mathrm{g} \mathrm{mL}{ }^{-1}$. The treated/ untreated sets of MSM were incubated at $28 \pm 2{ }^{\circ} \mathrm{C}$ on rotary shaker spinning at $150 \mathrm{rpm}$ and growth was measured spectrophotometrically (UV-2600, Shimadzu, Japan) at $620 \mathrm{~nm}$ at $2 \mathrm{~h}$ regular intervals each up to $24 \mathrm{~h}$. The absorbance was plotted as a function of kitazin concentrations and time.

\subsection{Kitazin induced cellular damage to strain RP1 under scanning electron (SEM), transmission electron microscopy (TEM) and CLSM}

Cellular damage to the bacterial strain R. leguminosarum RP1 was observed under SEM (JSM 6510LV JEOL, Tokyo, Japan) after growing the bacterial culture in nutrient broth $\left(\mathrm{gL}^{-1}\right.$ : peptone 10 ; beef extract $10 ; \mathrm{NaCl}_{5} ; \mathrm{pH}=7$ ) treated with $1200 \mu \mathrm{g} \mathrm{mL}^{-1}$ kitazin. Also, toxicity of kitazin to strain RP1 was observed under Confocal Laser Scanning Microscopy (CLSM). For TEM analysis, bacterial cells were fixed $\left(1 \% \mathrm{OsO}_{4}\right)$ for $1 \mathrm{~h}$, washed with $1 \times$ PBS and the fixed dehydrate $(30,50,70,90$ and $100 \%$ ethanol) for 5 min each and embedded in white resin overnight. Ultrathin sections (50-70 nm thickness) were cut with a microtome diamond knife, stained with $2 \%$ uranyl acetate and counter stained with $2 \%$ lead citrate. The sections were 
mounted on carbon coated copper grids and finally the changes in internal structures of cells, if any were observed under HRTEM (Technai, FEI, Electron Optics, USA).

\subsection{In vitro assessments of kitazin induced toxicity to pea plants}

2.7.1 Seed germination efficiency and microscopic examination of root tip distortion. Surface sterilized seeds of $P$. sativum $(3 \% \mathrm{NaOCl})$ were allowed to germinate on $0.7 \%$ soft agar plates supplemented with 0 (untreated control), $1 \times, 2 \times$ and $3 \times$ concentrations of kitazin at room temperature. After 5 days, percent germination, length of radicle (RL), plumule (PL) and seedling vigor index (SVI) were recorded. Further, the toxic and damaging effect of kitazin on morphological structure of pea roots were observed under SEM..$^{30}$

2.7.2 Quantification of cellular damage and cytotoxicity using CLSM. Kitazin induced cellular damage in pea roots was qualitatively assessed. For this, roots detached from plants grown with kitazin were stained using a cell-permeable fluorogenic probe $\left(2^{\prime}, 7^{\prime}\right.$-DCFH-DA) and propidium iodide (PI) and kept in dark for $10 \mathrm{~min}$ at room temperature (RT). After staining, root tissues were washed using PBS (0.1 M) to remove extra stain, mounted on slides and were viewed under CLSM. Loss in cell survivability of $P$. sativum plants was observed by means of Evan's blue dye technique. To determine loss of cellular viability, kitazin treated roots of peas were stained with Evans dye $(0.2 \% \mathrm{w} / \mathrm{v})$ for $10 \mathrm{~min}$ and successively washed with double distilled water (DDW) for half an hour. Samples were then analysed under CLSM to assess the cell death.

\subsection{Crop based experiments}

2.8.1 Seed biopriming, fungicide treatment and plant culture. Sterilized seeds of $P$. sativum var. Arkil were inoculated with $R$. leguminosarum RP1 by soaking the seeds in liquid culture medium for $2 \mathrm{~h}$ using $10 \%$ gum Arabic as adhesive to achieve $10^{8}$ cells per seed. The un-inoculated but sterilized seeds dipped in sterile water only were taken as control. A total of 10 non-inoculated and inoculated seeds were sown separately during rabi season in earthen pots containing three kilograms of unstressed conventional soils. Kitazin at $96(1 \times), 192(2 \times)$ and $288 \mu \mathrm{g} \mathrm{kg}^{-1}(3 \times)$ were added to each experimental pot and mixed homogenously. There were 8 treatments and each individual treatment was repeated three times. Experimental pots were set up in a complete randomized design (CRD) and three plants were retained in every pot seven days after emergence. Pots were watered regularly and were kept in an open field condition ( $9 \mathrm{~h}$ photoperiod/15 h dark cycle). The crop experiments were carried out regularly for two years (November to February 2016-17 and 2017-18) to achieve consistency in results.

2.8.2 Assessment of growth, photosynthetic pigments, symbiotic traits, nutritional content and grain features. One plant from each pot ( $n=3$ plants) for each treatment was uprooted at 90 days and remaining plants (two plants/pot) in three pots were harvested at 130 DAS. The detached plants were used to measure growth and symbiotic attributes. Plants were then oven-dried and dry matter was measured. Similarly, for photosynthetic pigments (chlorophyll $a, b$, total chlorophyll), carotenoids, and leghaemoglobin (LHb) estimation, one plant from each pot was taken. The pigment was determined ${ }^{31}$ in inoculated/non-inoculated pea leaves while LHb accumulated in nodule tissues ${ }^{32}$ was assayed after 90 days of growth. The total $\mathrm{P}$ and $\mathrm{N}$ content in dried roots and shoots of $P$. sativum removed at 130 DAS were measured by the method of Jackson ${ }^{23}$ and Lindner, ${ }^{33}$ respectively. Grain features such as seed yield and seed protein was estimated at harvest. ${ }^{34}$

2.8.3 Proline bioassay, malondialdehyde (MDA) and extraction of antioxidant enzymes. Proline content in fresh plant tissues (1.0 gram) collected from different organs (root, shoot and leaves) were determined at 90 DAS while in grains it was estimated at harvest. ${ }^{35}$ The extent of lipid peroxidation was evaluated by measuring MDA by the method of Heath and Packer $^{36}$ and the result was expressed as $\mu \mathrm{mol} \mathrm{MDA}{ }^{-1}$ fresh weight. Antioxidant enzymes such as $\mathrm{CAT},{ }^{37} \mathrm{POD},{ }^{38} \mathrm{APX}^{39}$ and $\mathrm{GPX}^{\mathbf{4 0}}$ in fresh leaves were detected at 90 DAS. All enzyme assays were performed three times with three replicates.

\subsection{Anatomical and cytological destruction of nodules}

The anatomical and cytological changes in pea nodules following the exposure to kitazin were monitored using 90 days old P. sativum plants. For this, nodules were fixed in $2.5 \%$ glutaraldehyde with $0.25 \mathrm{M}$ sucrose. Samples were then washed with $0.2 \mathrm{M} \mathrm{C}_{2} \mathrm{H}_{12} \mathrm{AsNaO}_{5}$ buffer ( $\mathrm{pH}$ 7.2). Then washed three times (every time for half an hour), post fixed in $1 \% \mathrm{OsO}_{4}$ prepared in $\mathrm{C}_{2} \mathrm{H}_{12} \mathrm{AsNaO}_{5}$ buffer (at $4{ }^{\circ} \mathrm{C}$ ) for 2 days. Cells were then dehydrated, dried in critical point drier (CPD). Finally, samples were mounted on $\mathrm{Cu}$ stubs with carbon coated with gold and examined and images were recorded.

\subsection{Root colonization of bacterial strain by SEM and CLSM}

Uninoculated and RP1 inoculated roots of P. sativum were used to observe $R$. leguminosarum establishment inside the root tissues. For this, roots were washed carefully with $\mathrm{H}_{2} \mathrm{O}$ and PBS. Roots were fixed for overnight in $2 \%$ (v/v) glutaraldehyde prepared in 0.1 M PBS ( $\mathrm{pH} 7.0$ ), washed thrice and dehydrated, dried in CPD, fixed on Cu stubs with carbon coated with gold stubs and viewed under SEM (JSM 6510LV SEM JEOL, Tokyo, Japan) at USIF, AMU, Aligarh.

\subsection{Statistical analysis}

In vitro experiments were carried out in three replicates and statistical analyses were performed using DMRT test at 5\% probability level by software, SPSS 10 . The pot experiments were conducted for two consecutive years (2016-17 and 2017-18) under identical environmental conditions using same treatments. Since data of measured parameters obtained were homogeneous, they were pooled together and subjected to ANOVA by applying two-way ANOVA [for two-factor (inoculation and fungicide concentration)] at 5\% probability level using software, Mini-Tab 17.0. Moreover, the differences among treatment means was compared by honestly significant difference (HSD) using Duncan multiple range (DMRT) test at 5\% 
Table 2 Morphological and biochemical features of strain RP1

Rhizobium leguminosarum

Characteristics strain RP1

Morphological
Colony
Shape
Gram reaction
Biochemical
Citrate
Indole
Methyl red
Nitrate reduction
Oxidase
Catalase
Hydrolysis
Starch
Gelatin
Lipid
Carbohydrate utilization
Dextrose
Lactose
Mannitol
Sucrose
Accession no.

Mucoid

Short rod

- ve

++
-
-
+
+
+
+
+
+
+
+
+
-
+
+
KY940047

probability level. The principal component analysis (PCA) was performed by Minitab Mtb EXE (2) software.

\section{Results and discussion}

\subsection{Morpho-biochemical characterization and molecular identification of bacterial strain}

Bacterial colonies of strain RP1 isolated from pea nodules was transparent, circular, mucoid and light pink in colour.
Microscopic analysis of strain RP1 revealed G-ve short rods and which exhibited positive reactions towards oxidase, citrate and catalase, nitrate reduction, and hydrolysed starch and gelatin (Table 2). The pattern of carbohydrate utilized by bacterial strain RP1 varied significantly. Based on morpho-biochemical features, microscopic examination and nodulation test, strain RP1 was found to belonged to genus Rhizobium. Furthermore, nucleotide sequences of gene of 16S rRNA of RP1 strain (approximately 844 bp in size) submitted to GenBank (accession number KY940047) when searched through BLASTn programme, confirmed strain RP1 as Rhizobium leguminosarum. Later, a phylogenetic tree was constructed by MEGA 6.0 software, based on 16S rRNA partial gene sequences (Fig. 2).

\subsection{Bacterial tolerance to kitazin}

Fungicide use is a common practice in agricultural system to shield the consumable crops from nuisance of phytopathogens and hence, to optimize productivity of food crops. However, excessive use of such agro-chemicals leads to decrease in - (i) crop production (ii) development of tolerance/resistance to such agricultural chemicals among plant beneficial soil microbiota and (iii) emergence of resistance among insects-pests also. To overcome these situation, fungicide resistant bacterium was isolated from nodules of $P$. sativum and was later used as microbial inoculant for augmenting legume production in fungicide polluted soil. Here, pea nodulating bacterium $R$. leguminosarum RP1 when exposed to variable doses of kitazin, this strain survived well at $2400 \mu \mathrm{g} \mathrm{mL}{ }^{-1}$ of kitazin and grew well on $\mathrm{C}$ - and $\mathrm{N}$-source-free minimal salt agar (MSA) plates amended with fungicide. Indeed, the tolerance or resistance feature of soil microorganisms against fungicides is of course a complex process which is regulated both at physiological and

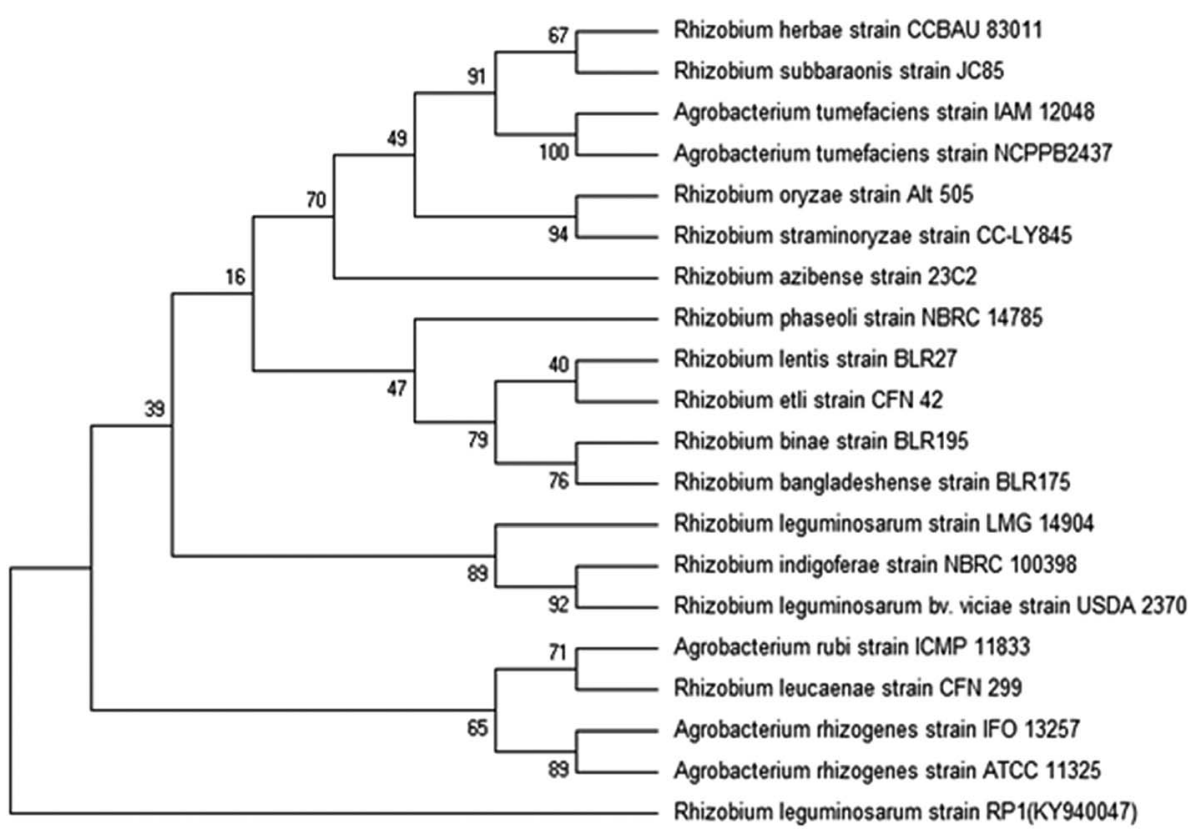

Fig. 2 Phylogenetic tree representing the relationship of Rhizobium leguminosarum strain RP1. A neighbour-joining tree was calculated using partial 16S rRNA gene sequences (bp) and a frequency filter included in the ARB software package. Accession numbers of the National Centre for Biotechnology Information (NCBI) database of each strain are given in brackets. 
genetic level. Hence, microbial inoculants capable of tolerating/ accepting higher level of pesticides have been reported as frequent degrader of these agrochemicals also. As the minimal salt medium (MSM) used to identify kitazin tolerant strain $R$. leguminosarum did not contain $\mathrm{C}$ and $\mathrm{N}$ sources, but only fungicide, it is hypothesized that strain RP1 might have consumed the fungicides as a sole or supplementary source of energy by biodegrading kitazin and thus, exhibited maximum tolerance to test fungicide used in this experiment. The ability of strain RP1 to tolerate higher level of kitazin provides two important scientific and practicable information's - (i) whenever and wherever there is kitazin pollution, strain RP1 $R$. leguminosarum can thrive well without losing its physiological functions and (ii) if applied as inoculant even under fungicide stress, are likely to facilitate the crop production.

\subsection{SEM \& CLSM based assessment of kitazin induced toxicity to nodule bacterium}

3.3.1 Growth pattern, surface morphology and cellular permeability. The growth behaviour of fungicide tolerant nodule bacterium ( $R$. leguminosarum strain RP1) assayed in liquid MSM amended with variable concentrations of kitazin differed considerably. In general, growth of RP1 was initially slow (lag phase) which though, improved rather linearly in late lag, log and stationary phases and decreased sharply afterwards (Fig. 3A). The $3 \times$ of kitazin had more toxic effect on growth of bacterial cells than other rates of kitazin. However, at $3 \times$ concentration, strain RP1 even though survived, but growth was poor. In other words, this could be an interesting feature which will allow strain RP1 to survive and grown even under harsh (stressed) environment.

Further, toxicity of kitazin was assessed on morphology and permeability of bacterial cells using electron microscopic techniques. The SEM images revealed a distinct, unruptured, smooth and intact bacterial cell when grown in liquid medium without fungicide (Fig. 3A). Whereas, images of bacterial cells treated with $1200 \mu \mathrm{g} \mathrm{mL} \mathrm{mL}^{-1}$ of kitazin appeared as damaged, ruptured, broken and mis-shaped surface. For permeability determination, bacterial cells grown in liquid broth supplemented with different kitazin concentration were examined under CLSM. Dead/inactive cells were red coloured short rods due to PI staining of nucleic acid (DNA) of bacterium. With enhancing kitazin concentration, red fluorescence was increased because PI binds with DNA in cellular membrane and as a result the number of dead cells also increased. Whereas, cell membranes of active/live cells take the AO and appeared as green short rods (Fig. 3B). As stressor molecules binds/attaches the bacterial membrane by electrostatic interaction, it (interaction) activates initiation of oxidative stress leading to the formation of free radicals (ROS). These free radicals interrupt bacterial cell membrane and ultimately PI is taken up by bacterial cells. Similarly, reduced cell viability because of increased oxidative stress induced by different fungicide species in $B$. subtilis has very recently been reported. ${ }^{41}$
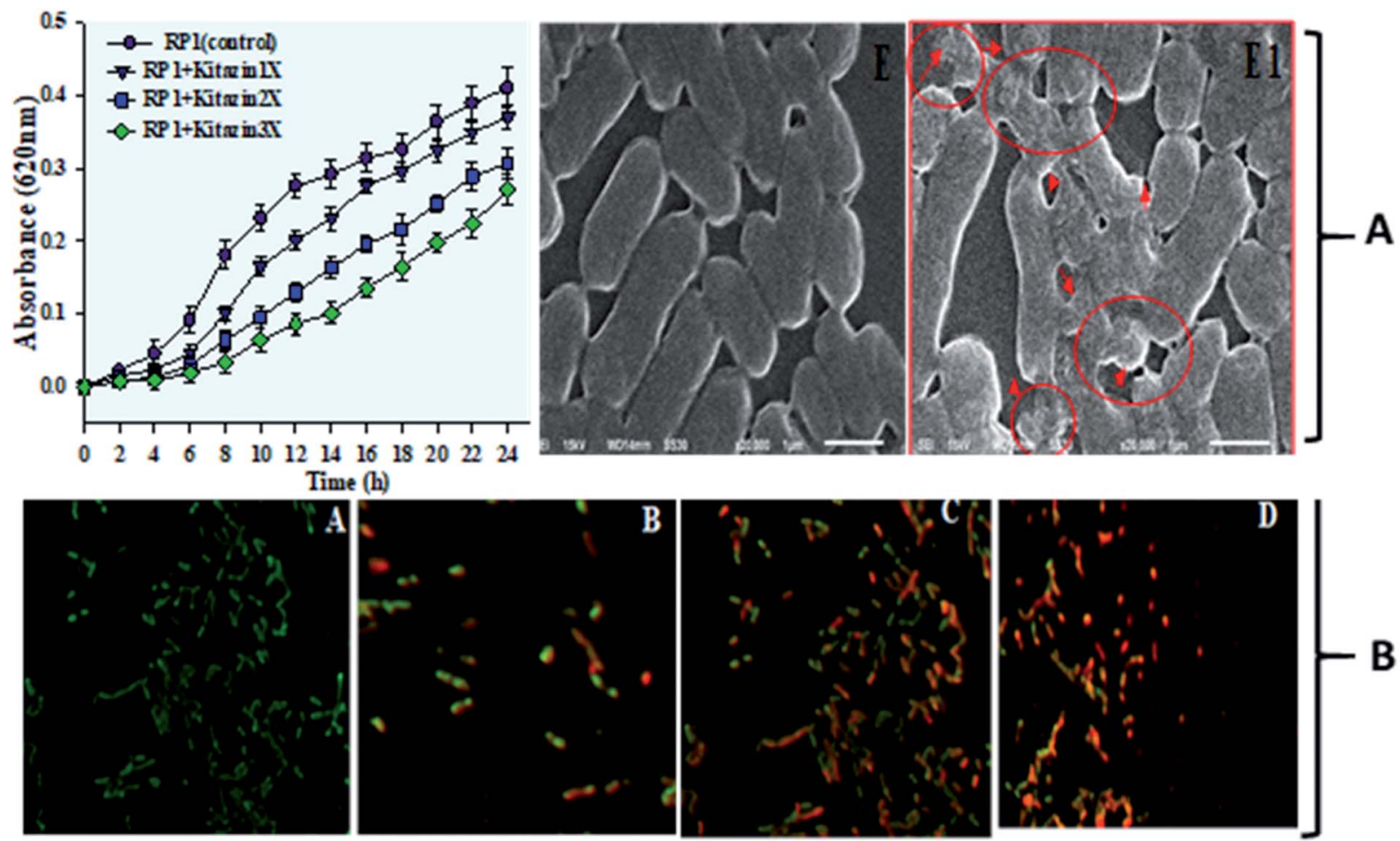

Fig. 3 Depicts the growth pattern of $R$. leguminosarum strain RP1 grown in minimal medium supplemented with increasing concentrations of kitazin as a function of time of incubation at $28 \pm 2{ }^{\circ} \mathrm{C}$. Data represent the mean $\pm \mathrm{S}$. D of three independent experiments done in triplicate (A). Control and kitazin treated SEM micrograph of strain RP1 (red coloured arrows indicate the damage/rupture in cells after exposure to kitazin (A)). CLSM images of live/dead cells of $R$. leguminosarum strain RP1 stained with AO/PI indicating the cell viability (A) control (B-D) treated with 600 , 1200 and $1800 \mu \mathrm{g} \mathrm{mL}^{-1}$ kitazin (B). 
3.4 Phytohormone, cyanogenic compounds and $\mathrm{NH}_{3}$ production under kitazin stress

Kitazin tolerant RP1 strain revealed inconsistent production of plant growth bioactive molecules when grown both in fungicide stress and controlled conditions (Table 3). Generally, the quantum of plant growth regulators secreted by RP1 decreased with increasing kitazin concentrations. For instance, under fungicide free environment, strain RP1 released $80.5 \pm 2.5 \mu \mathrm{g}$ $\mathrm{mL}^{-1}$ of IAA which declined regularly with consistent increase in kitazin concentration but a maximum reduction in IAA synthesis was recorded at $3 \times\left(15.6 \pm 0.5 \mu \mathrm{g} \mathrm{IAA} \mathrm{mL}^{-1}\right)$. In line with these findings, Verma et al. $^{42}$ have also reported similar secretion of IAA by various rhizosphere microbes. The production of IAA even at higher fungicide concentration indeed is a fascinating and encouraging property of soil microbiota, because such fungicide tolerant microbes when applied under fungicide contaminated soil are most likely to continue secreting IAA and making this essential growth enhancing phytohormone available to plants even under fungicide polluted soils. Therefore, the present outcome of this study suggests that while secreting IAA under pressure situations, bacterial strains are helping plants directly in many ways like, facilitating growth, affecting cell division, root morphogenesis, symbiosis, apical dominance, phototropism and geotropisms. Cyanogenic compound ( $\mathrm{HCN})$ and ammonia $\left(\mathrm{NH}_{3}\right)$ produced by RP1 strain was however, not detected at $3 \times$ concentration of kitazin which has also been echoed by others. ${ }^{\mathbf{4 3 , 4 4}}$

\subsection{Phosphate solubilization, siderophores and ACC deaminase}

In general, efficiency of P-solubilization of strain RP1 decreased constantly with increasing concentrations of kitazin. Like other measured biomolecules, maximum decline in P-solubilization was also noticed at $3 \times$ concentration of kitazin $(15.6 \pm 0.5 \mu \mathrm{g}$ $\mathrm{mL}^{-1}$ ), which decreased solubilized $\mathrm{P}$ by $50 \%$ compared to untreated control $\left(31.5 \pm 1.8 \mu \mathrm{g} \mathrm{mL}^{-1}\right)$. The SE of strain RP1 varied between $2.3(1 \times)$ to $2(3 \times)$ while, SI differed between 126 $(1 \times)$ to $108(3 \times)$. In many studies, phosphate solubilizing activity of PGPR has been found to vary due to differences in their ability to secrete low molecular weight organic acids such as $\alpha-2$ keto gluconic, oxalic, gluconic, acetic, malic, citric and succinic etc. that results in drop in $\mathrm{pH}$. Like other plant growth regulators, production of phenolate type siderophores including salicylic acid and DHBA also decreased considerably under varying rates of kitazin. For example, SA and DHBA secreted by $R$. leguminosarum RP1 in fungicide free medium was $54 \pm 7.3$ and $31.9 \pm 2.7 \mu \mathrm{g} \mathrm{mL}{ }^{-1}$, respectively, which however, declined to $21.9 \pm 1.6(59 \%)$ and $11.3 \pm 0.6 \mu \mathrm{gL}^{-1}(64 \%)$, respectively at $1800 \mu \mathrm{g} \mathrm{mL} \mathrm{m}^{-1}$ of kitazin.

Siderophores, a low molecular weight iron chelating compound synthesized by microbial communities under iron starved conditions provide iron to plants under Fe-deficient conditions. ${ }^{45}$ Under aerobic environments, iron occurs principally as insoluble hydroxide and oxyhydroxide, which becomes inaccessible/unavailable to microbial communities. Therefore, synthesis of siderophores under iron starved condition could be

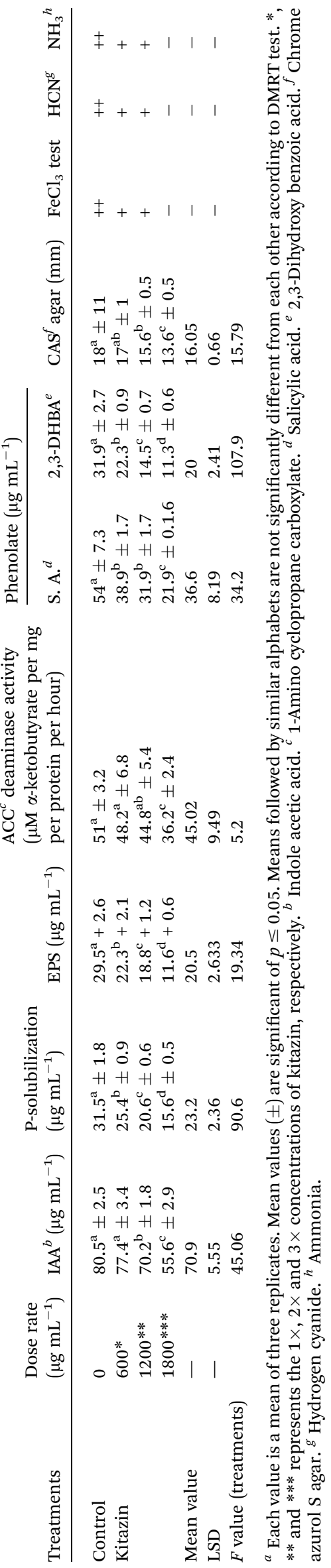


advantageous because such siderophores producing strains could be used in management of phytopathogens which requires higher amounts of iron for their growth and metabolic activities.

The 1-amino cyclopropane 1-carboxylate (ACC) deaminase released by numerous plant beneficial soil microbes is yet an outstanding biological attribute which reduces strangely the level of $\mathrm{C}_{2} \mathrm{H}_{2}$ in plants and thus, accelerates the functioning of growing plants under adverse conditions. ${ }^{46}$ In this study, strain RP1 demonstrated a positive reaction to ACC deaminase grown even with varying doses of fungicide. As kitazin concentration increased, a gradual decrease in quantity of $\alpha$-ketobutyrate was observed (Table 3). At $1800 \mu \mathrm{g} \mathrm{mL} \mathrm{m}^{-1}$ of kitazin there were highest inhibitory impact and release of ACC deaminase was declined maximally by $36.2 \pm 2.4 \mu \mathrm{M} \alpha$-ketobutyrate per $\mathrm{mg}$ per protein per hour $(29 \%)$ relative to untreated control $(51 \pm 3.2 \mu \mathrm{M} \alpha$-ketobutyrate per mg per protein per hour). The synthesis of $\alpha$-ketobutyrate by strain RP1 however, even in stressful environment could agriculturally be a valuable feature for upgrading crop production efficiency under fungicide stressed conditions. In other studies, several workers have also reported similar growth promoting impact of stress tolerating microbes on many crops. ${ }^{47}$

\subsection{How kitazin affects pea?}

3.6.1 Seed germination and distortion/damage in root tips. In order to understand the toxic impact of kitazin, pea seeds were exposed to various levels of kitazin and observed for changes in germination and distortion to roots under in vitro conditions. Under controlled conditions, percent germination, seedling vigour index (SVI), radicle (RL) and plumule (PL) length was found to be $95 \pm 5 \%, 1651 \pm 102,8.65 \pm 1.2 \mathrm{~cm}$ and $7.8 \pm 0.12 \mathrm{~cm}$, respectively. However, as concentration of fungicide increased, a significant reduction in such parameters was also observed. For instance, percent germination, SVI, RL and PL were significantly $(p<0.05)$ decreased by $35.7 \%(61.6 \pm$ $2.8), 87 \%(206 \pm 16), 72 \%(2.3 \pm 0.3 \mathrm{~cm})$ and $83 \%(1.2 \pm 0.2 \mathrm{~cm})$, respectively at $3 \times$ concentration of kitazin compared to untreated control (Fig. 4A). Similar toxic/inhibitory effect of varying concentrations of different toxic chemicals on seed attributes of mungbean have been reported. ${ }^{48}$

After it was established that kitazin indeed had deleterious impacts on growth of peas, its effect on structure/morphology of root tips of pea plants while growing in kitazin stressed environment was further assessed using SEM (Fig. 4B). The destructive impact of fungicide was of course more pronounced at radical region of root tips. The SEM images of damaged root tips clearly demonstrate a notable aberration, cracks/fissures, disintegration, spikes and ruptured surface (Fig. 4B) related to clear, smooth and intact/unbroken surface of control roots. These damages inflicted by fungicide further corroborated disruptive action of kitazin which in turn might have weakened uptake of water and nutrients by root systems from soils and consequently altering root growth. In a recent study, Shahid et $a{ }^{49}$ have also revealed inhibitory impact of fungicides on morphological structure of crops grown in fungicide polluted soils.
3.6.2 Cellular damage and cytotoxicity assessment. Cell membrane being selectively permeable allows molecules to move inside and to interact them intracellularly. So, to better understand the toxic effect of chemical compounds on this vital biological membrane, integrity of membranes was examined under microscope. For this, Confocal laser scanning microscopy (CLSM), a most elusive and reliable tool which involves use of acridine orange (AO) and propidium iodide (PI) to differentiate between viability and toxicity of cells was employed. Principally, PI, a small hydrophilic molecule is impermeable to membrane of viable cells and therefore, is rejected by living cells but it does penetrate damaged membrane of dead cells having and interpolates dsDNA and emits red fluorescence.

Remarkably, a dose dependent increase in number of dead cells was observed in roots treated with various concentrations of kitazin as compared with untreated control (Fig. 4C). The cellular damage caused due to fungicide was clearly visible in fluorescent micrograph and more so intensity of red fluorescence emitted by PI increased continuously with increasing concentrations of kitazin. The increasing cellular damage highlights generation of enhanced oxidative stress in P. sativum plants while growing under fungicide stress. In accordance with this finding, Grossmann et al. ${ }^{\mathbf{5 0}}$ recently reported the imaging of living plant cells using CLSM. The results obtained in this study henceforth confirms the fact that most decisive target of fungicide was cell membrane as also reported for other stressor molecules.

The loss/damage of plasma membrane in root tissues of pea plants under different doses of kitazin was apparent when roots were stained with Evans blue dye. With increase in kitazin concentration, dye uptake by root tissues also increases 3-4fold, and subsequently results in losses in plasma membrane integrity. For instance, $2 \times$ and $3 \times$ doses of kitazin used in this experiment also validated similar increase in intensity of blue fluorescence related to fungicide untreated/control root sample. The untreated/control root samples did not take up dye and hence, root periphery remained smooth suggesting a more active and fully functional integrity of plasma membrane (Fig. 4C). These findings further affirm the concept that agrochemicals including synthetic fungicides may rupture cellular and plasma membrane that eventually become the reason of cell death.

\subsection{Phytotoxicity of kitazin to pea plants and stress remediation by $R$. leguminosarum}

3.7.1 Height and dry phyto-mass. The inoculated and uninoculated pea plants developed in soils treated with varying doses of kitazin had variable growth (Fig. 5A-E). Over all, measured biological parameters of pea plants diminished with increasing fungicide concentrations. Bio inoculated pea plants in contrast of course had better growth which increased with age of plants, compared to those of non-inoculated one. However, biological attributes of plants even inoculated with rhizobial strain RP1, declined significantly when grown along with the fungicide related to plants cultivated in kitazin free soil. For instance, $R$. leguminosarum RP1 strain when applied 

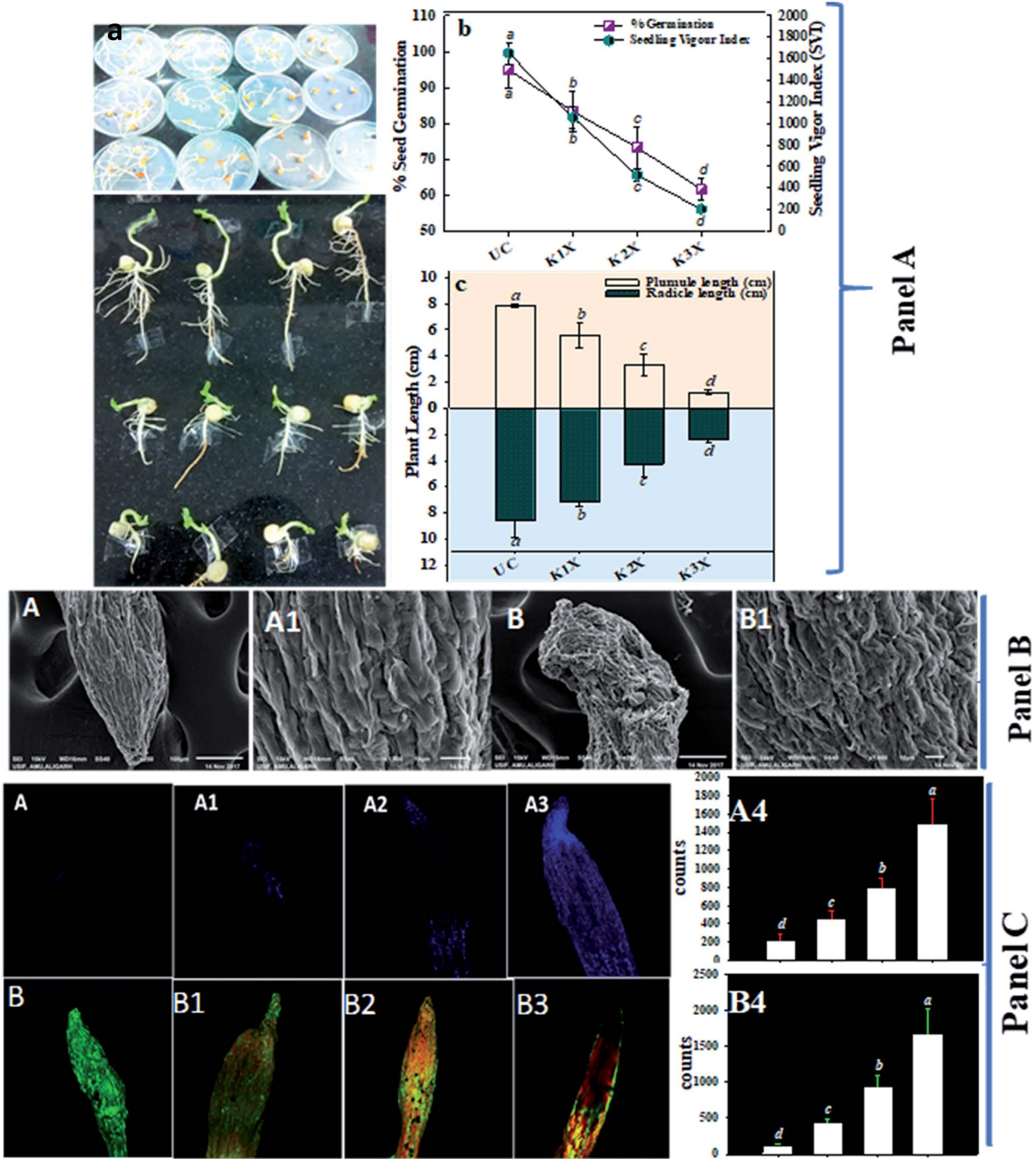

Fig. 4 Panel (A) represents the toxic and inhibitory impacts of fungicide on seeds germinated on $0.7 \%$ soft agar plates amended with 0 (control), $1 \times, 2 \times$ and $3 \times$ concentrations of kitazin (a), \% seed germination and seedling vigor index (b), length of radicle and plumule after 5 days of germination (c). Each value is a mean of five replicates $(n=5)$ where each replicate constituted five seeds/plates. Mean values followed by different letters are significantly different at $p \leq 0.05$ according to DMRT test. Vertical bars represent means \pm SD $(n=5)$. ANOVA significant at $p \leq 0.05$. Panel (B) represents the SEM micrograph of $P$. sativum roots grown on soft agar under in vitro conditions: (A) and (A1) are root tip and root surface of untreated control, whereas, (B) and (B1) shows damaged/fractured and fissures in kitazin treated root tip and surface, respectively. Panel (C) shows the Z-stack CLSM micrographic analysis of $P$. sativum roots; (A), (A1), (A2) and (A3) depicts the cytotoxicity (Evans blue dye exclusion) assay; figures shows the uptake of Evans blue dye by root cells; (A) is untreated control showing no blue colour, whereas, (A1), (A2) and (A3) are $1 \times, 2 \times$ and $3 \times$ kitazin treated roots showing the uptake of dye, respectively. As the conc. of fungicides increased, the intensity of blue fluorescence increased. (B), (B1), (B2) and (B3) represents the 0 (untreated control), $1 \times, 2 \times$ and $3 \times$ kitazin treated, respectively and propidium iodide $(\mathrm{PI}) /$ acridine orange $(\mathrm{AO})$ stained roots of $P$. sativum represent the oxidative stress and cellular damage induced by fungicides. Images reveal an increase in red/orange fluorescence as the concentrations of fungicides increases. 
with $2 \times$ concentration of kitazin, improved dry biomass of shoots and roots by 28.3 and $7.6 \%$ at 90 days and 43 and $11.5 \%$ at 130 days after sowing, respectively, compared to plants which were raised with similar fungicide rate (Fig. 5F). Whereas, impact of bacterial inoculant ( $R$. leguminosarum) on pea plants raised in soils treated with $288 \mu \mathrm{g} \mathrm{kg}^{-1}$ kitazin, compared to those of only fungicide amended soil, caused a maximum increase of $37 \%, 9.7 \%$ and $34 \%, 3.6 \%$ in root and shoot dry mass at 90 and at 130 days after sowing of plants, respectively related to kitazin de-stressed and un-inoculated plants. Twoway ANOVA showed that impacts of inoculation and fungicide was significant $(p \leq 0.05)$ for all measured biological parameters. The associative effects of inoculation and kitazin was noteworthy for all measured biological attributes at 90 and 130
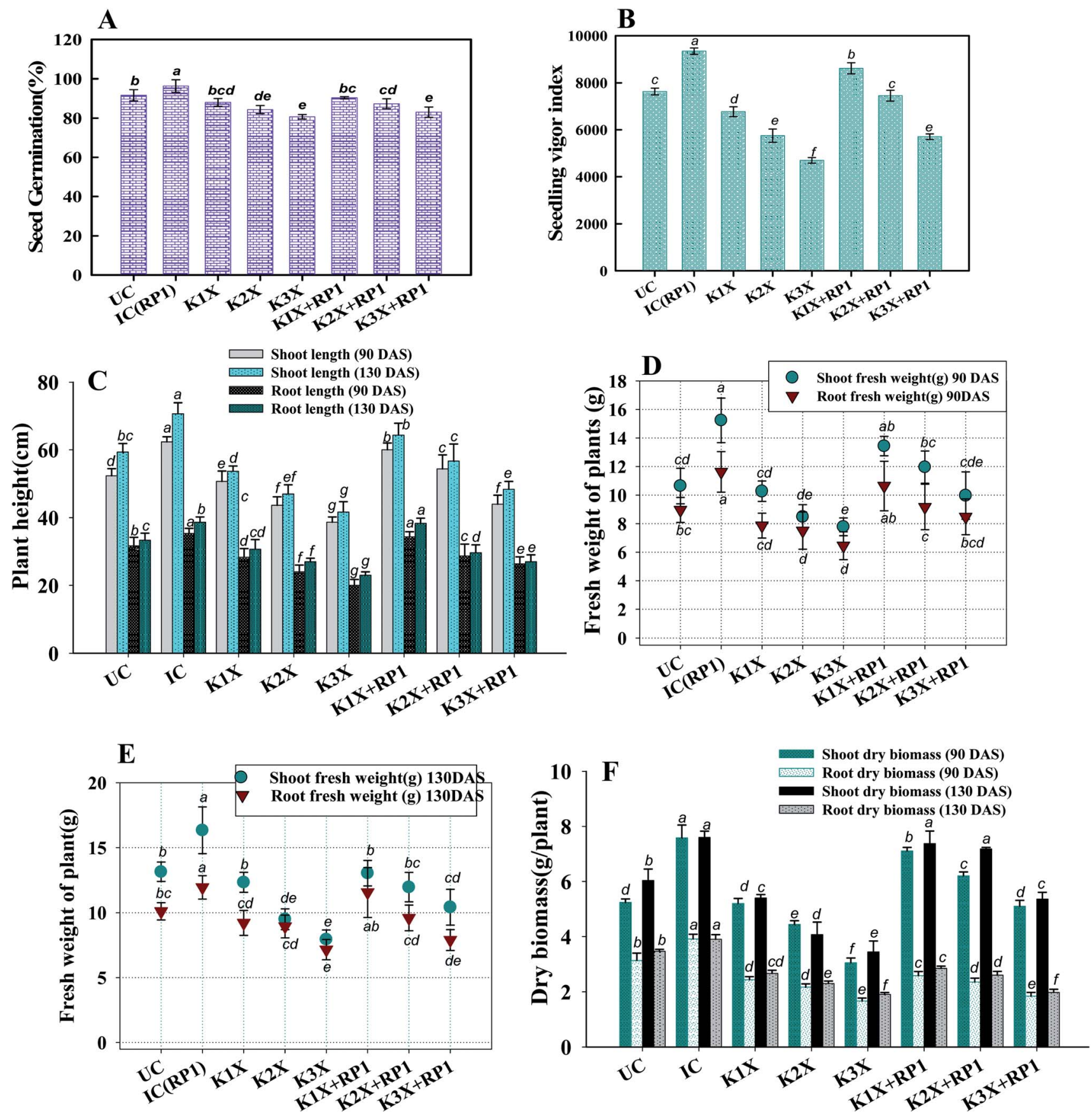

Fig. 5 Impact of fungicide tolerant bacterial strain (FTBS) R. leguminosarum RP1 on different growth parameters of Pisum sativum plants grown in sandy clay loam soils treated with recommended $(1 \times)$, two times $(2 \times)$, and three times $(3 \times)$ more of recommended dose of kitazin $-(A)$ percent seed germination (B) seedling vigor index (C) length of plant organs (root and shoot) (D) dry biomass of root and shoot (E) fresh weight of plant organs at 90 DAS and (F) weight of plant organs at 130 DAS. Here, symbol UC represents Uninoculated and untreated control, IC represents Untreated control inoculated with strain RP1. Each value is a mean of three independent replicates $(n=3)$ where each replicate constituted three plants/pot. Mean values followed by different letters are significantly different at $p \leq 0.05$ according to DMRT test. Vertical and scattered bars represent means $\pm \mathrm{SD}(n=3)$. ANOVA significant at $p \leq 0.05$. 
DAS. Like any conventional plant growth promoting rhizobacteria, fungicide tolerant $R$. leguminosarum RP1 applied as a potent bioremediating agent in this study also triggered a remarkable upsurge in inclusive/overall functioning of pea plants which could probably be due to production/release of plant growth regulators by microbes. ${ }^{51}$ Among these active biomolecules, IAA for instance, incites root growth directly by affecting root morphogenesis, stimulating cell elongation or cell division. ${ }^{52}$ As a result of these, expanded/prolonged roots absorb more water and minerals from soil and therefore plants grow better. Other factors that could be responsible for improvement in overall performance of pea plants are accessibility of vital nutrients like P, siderophores, HCN and ACC etc. released by bacterium in rhizosphere.

3.7.2 Photosynthetic pigments and symbiotic features. In this study, chlorophyll forming ability (Table 4) and symbiotic characteristics (number, biomass and leghaemoglobin content of nodule) of fungicide treated but non-inoculated peas, declined persistently with consequent increase in kitazin concentration (Fig. 6). For instance, kitazin at $192 \mu \mathrm{g} \mathrm{kg}$ reduced formation of photosynthetic pigments such as chl $a$, chl $b$, total chlorophyll and carotenoids contents by $19.3,17.6$, 12.8 and $8.4 \%$, respectively, related to non-inoculated peas (Table 4). In contrast to these, a further reduction of 29, 17.8, 16 and $16 \%$ in chl $a, b$, total and carotenoids was observed at 288 $\mu \mathrm{g} \mathrm{kg}{ }^{-1}$ kitazin. While assessing the stress relieving potential of $R$. leguminosarum RP1 strain, it was found that a maximum increase of 9.3, 11, 8.6 and $13.7 \%$ in chl $a$, chl $b$, total chl and carotenoid contents, respectively was recorded in inoculated peas grown at $96 \mu \mathrm{g} \mathrm{kg} \mathrm{kg}^{-1}$ kitazin. In contrast, bacterial inoculum at $192 \mu \mathrm{g} \mathrm{kg} \mathrm{kg}^{-1}$ even though improved chlorophyll and carotenoid contents, but enhancement in these pigments was marginal compared to those recorded in inoculated plants grown at lower kitazin concentration.

Number of nodules/plant (NN), nodule biomass (NB) and leghaemoglobin ( $\mathrm{LHb}$ ) contents were maximally decreased by 40,35 and $49 \%$, respectively at highest $\left(288 \mu \mathrm{g} \mathrm{kg}^{-1}\right)$ rate of kitazin, after 90 days of pea growth (Fig. 6A-C). Conversely, $R$. leguminosarum strain RP1 improved NN, NB and LHb content by $17.2,8.2$ and $13.6 \%$, respectively compared to plants grown in the presence of $96 \mu \mathrm{g} \mathrm{kg}^{-1}$ kitazin. The correlation between NN and NDB was positively correlated $\left(R^{2}=0.94\right)$. Similarly, LHb content and NN was strongly correlated $\left(R^{2}=0.95\right)$ (Fig. 7a). Similar phytotoxic influence of synthetic chemicals and stress alleviating ability of stress tolerant PGPR strains for example, Bradyrhizobium sp. and Pseudomonas sp. on many physiological activities including symbiotic characteristics of legumes developed in herbicide polluted soil has previously been reported. ${ }^{53}$

3.7.3 Seed attributes and nutrient uptake. Grain yield (GY) and seed protein (SP) of pea plants measured at harvest (130 DAS) showed a steady decline with consecutive increase in kitazin concentrations (Fig. 6D). On the contrary, GY and SP of bio-inoculated peas improved by 24 and 11.7\%, respectively, compared to non-inoculated control plants. In addition, fungicide tolerant $R$. leguminosarum RP1 increased GY and SP by 4.5 and $1.8 \%$ respectively, at $288 \mu \mathrm{g} \mathrm{kg}^{-1}$ dose rate of kitazin, compared to non-inoculated peas raised in fungicide stressed soils. The two-way ANOVA exhibited a significant collaborative impact of bio-inoculum $R$. leguminosarum and kitazin (bioinoculum $\times$ kitazin) on the measured seed features.

Table 4 Inoculation effect of fungicide tolerant Rhizobium leguminosarum strain RP1 on photosynthetic pigments and proline content of $P$. sativum plants grown in sandy clay soil supplemented with different doses of kitazin ${ }^{a}$

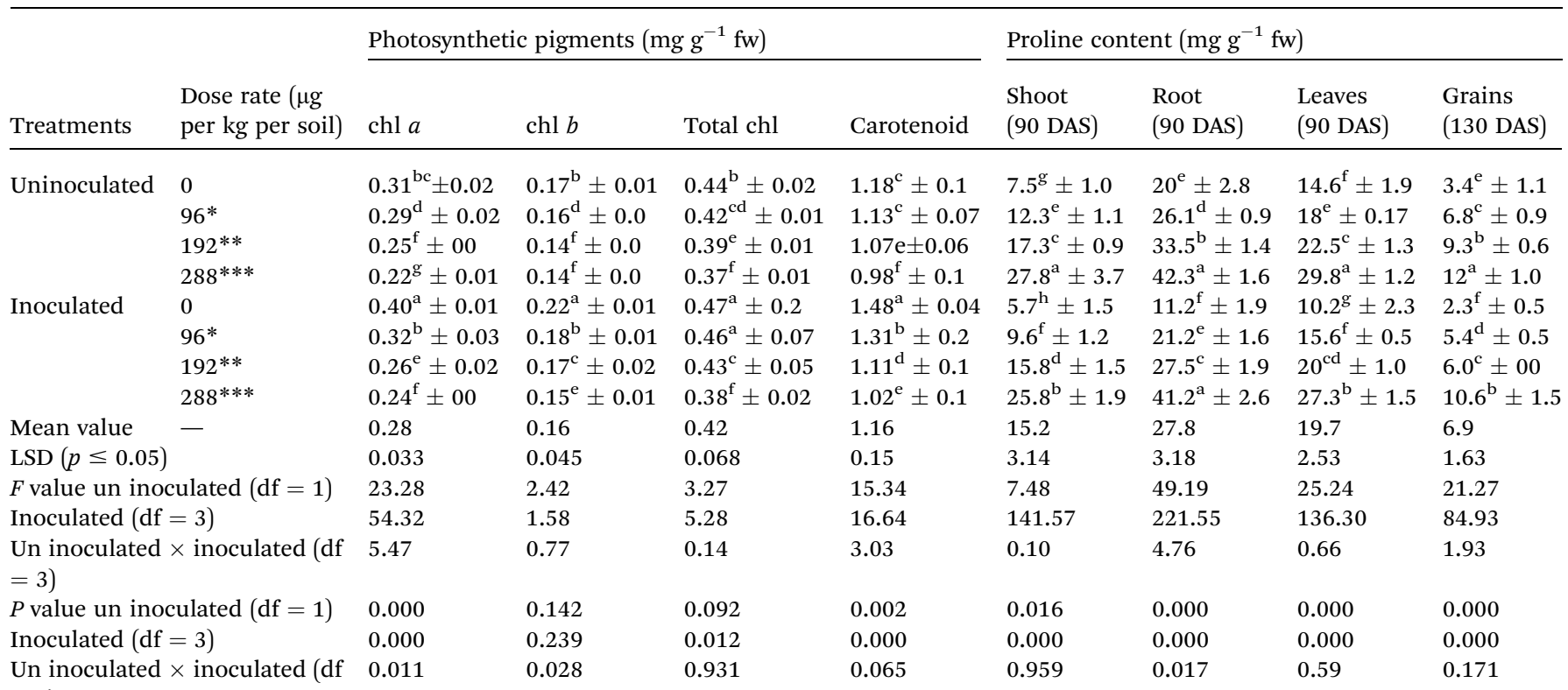
$=3)$

${ }^{a}$ Each value is a mean of three replicates where each replicate constituted three plants/pot. Mean values are significant at $p \leq 0.05$. Means followed by similar alphabets are not significantly different from each other according to DMRT test. *,** and *** represents the normal recommended $(1 \times)$, two times more $(2 \times)$ than recommended dose and three times more $(3 \times)$ than recommended doses of kitazin. 
The nutritional content ( $\mathrm{N}$ and $\mathrm{P}$ ) in roots and shoots of inoculated and uninoculated pea plants was variable. Kitazin at $2 \times$ when used alone, reduced the root $\mathrm{N}(\mathrm{RN})$, shoot $\mathrm{N}(\mathrm{SN})$, root $\mathrm{P}(\mathrm{RP})$ and shoot $\mathrm{P}(\mathrm{SP})$ by $12,13,16$ and $19 \%$, respectively.
Whereas, strain RP1 enhanced the RN, SN, RP and SP by 11, 9, 7 and $12 \%$, respectively, when peas were grown in soils contaminated with similar dose of kitazin (Fig. 6E and F). Two factor ANOVA displayed that single effect of inoculation and
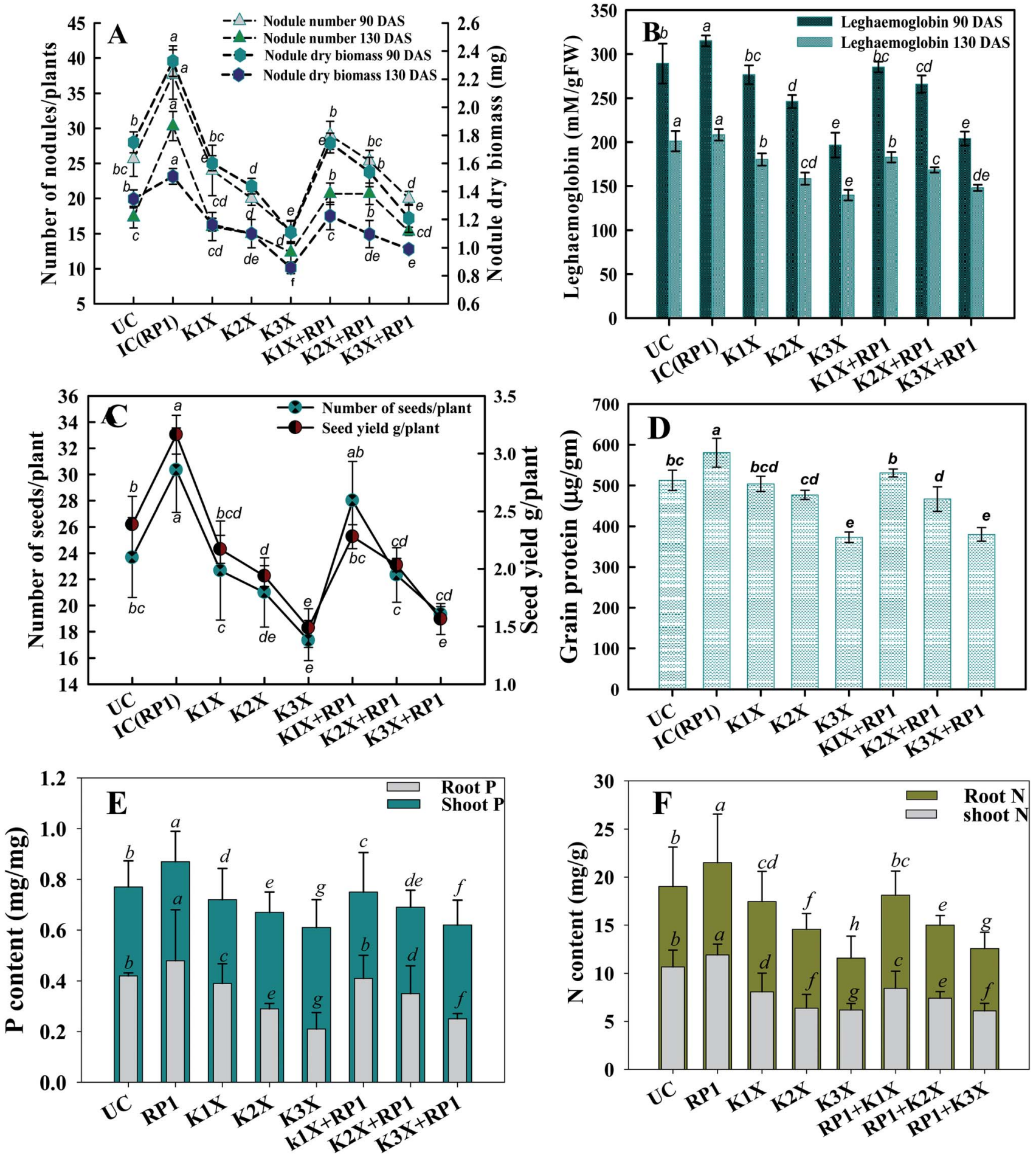

Fig. 6 Effect of fungicide tolerant $R$. leguminosarum RP1 on symbiotic attributes of Pisum sativum plants grown in sandy clay loam soils treated with recommended $(1 \times)$, two times $(2 x)$, and three times $(3 x)$ of recommended dose of kitazin - $(A)$ number and dry biomass of nodule (B) LHb content at 90 and 130 DAS. Seed features (C and D) and nutritional uptake i.e. phosphorous content (E) and nitrogen content (F). Here, symbol UC is for uninoculated and untreated control, IC is untreated control inoculated with strain RP1. Each value is a mean of three independent replicates $(n=3)$ where each replicate constituted three plants/pot. Mean values followed by different letters are significantly different at $p \leq 0.05$ according to DMRT test. Vertical and scattered bars represent means \pm SD $(n=3)$. ANOVA significant at $p \leq 0.05$. 
(a)
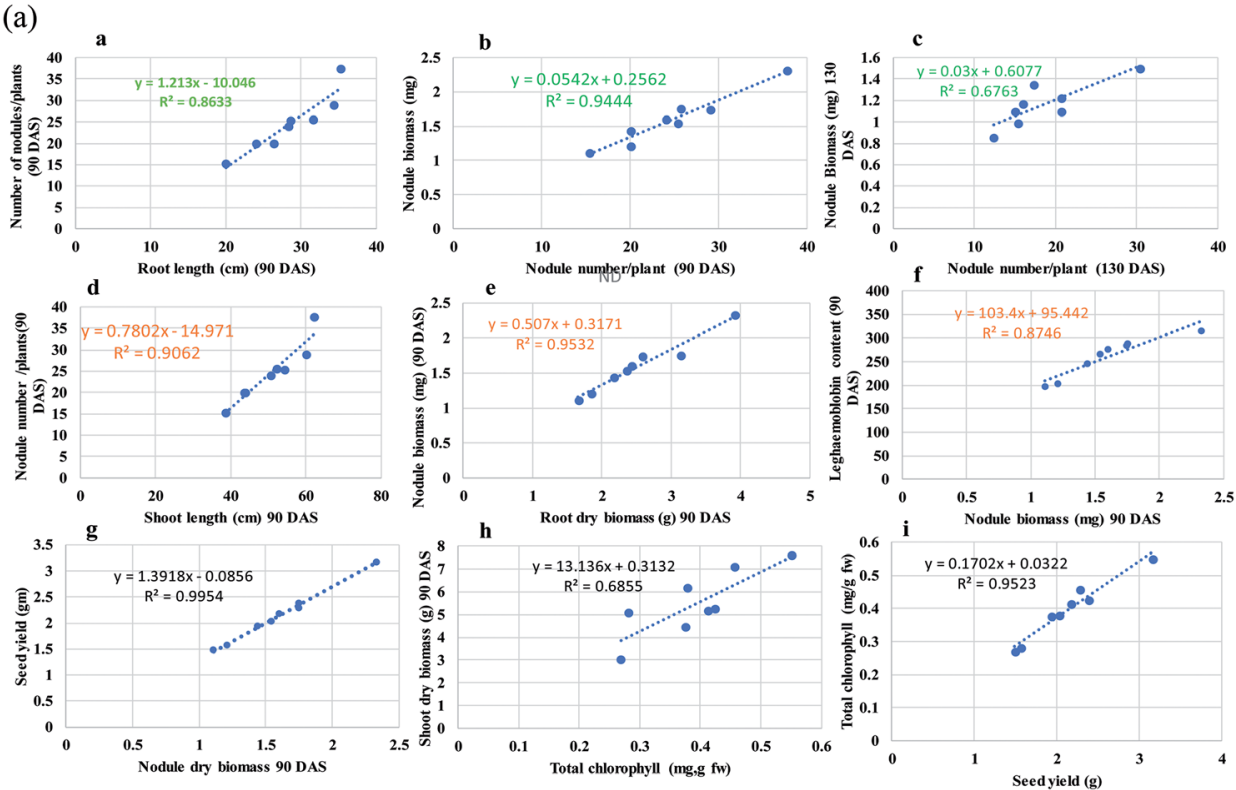

(b)
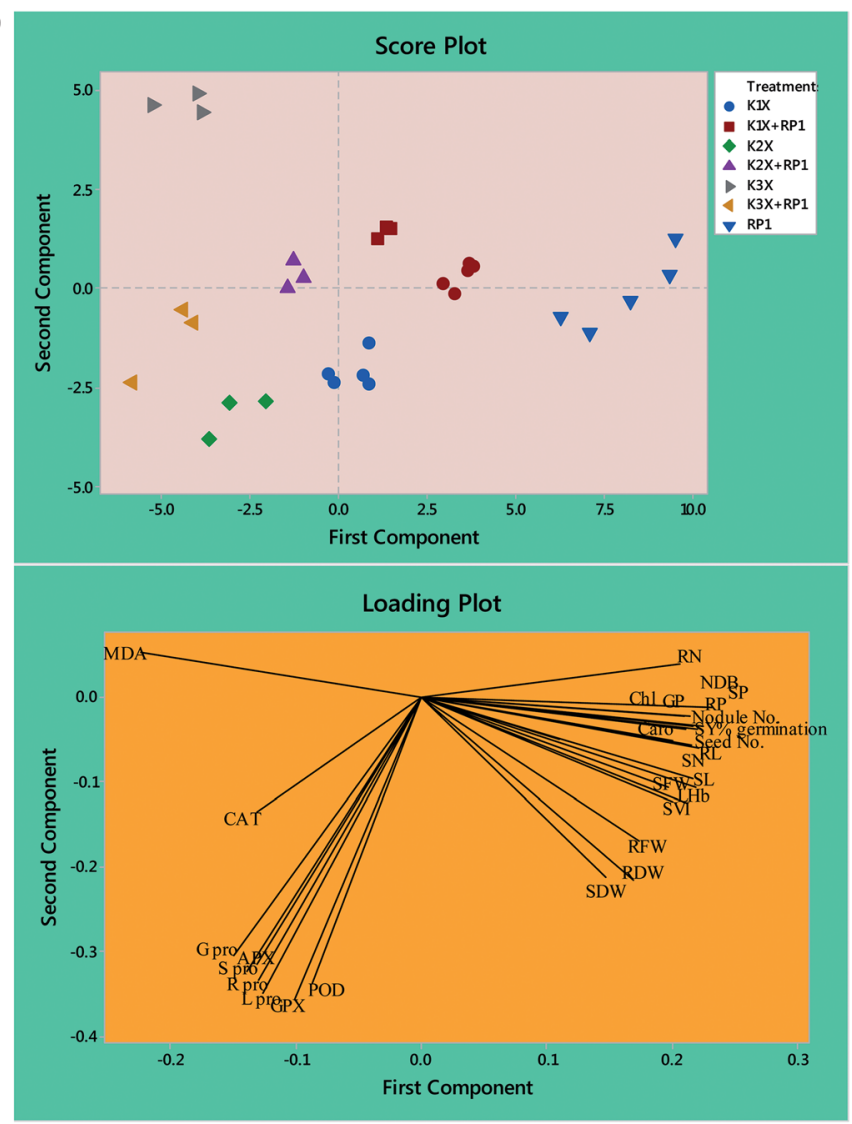

Fig. 7 (a) Linear regression between biological parameters of pea plants grown in sandy clay loam soil treated with varying concentrations of kitazin and inoculated with $R$. leguminosarum RP1; nodule number vs. root length $\left(R^{2}=0.96\right)$, nodule number (90 DAS) vs. nodule biomass $\left(R^{2}=\right.$ $0.94)$, nodule number (130 DAS) vs. nodule biomass $\left(R^{2}=0.77\right)$, nodule number vs. shoot length (90 DAS) $\left(R^{2}=0.90\right)$, nodule biomass vs. root dry biomass (90 DAS) $\left(R^{2}=0.95\right)$, nodule biomass vs. LHb content $\left(R^{2}=0.87\right)$, seed yield vs. nodule biomass $\left(R^{2}=0.99\right)$, shoot dry biomass vs. total chlorophyll content $\left(R^{2}=0.78\right)$, seed yield vs. total chlorophyll $\left(R^{2}=0.95\right)$. (b) Loading $(\mathrm{A})$ and score (B) plots showing the principal component analysis (PCA) of various parameters of pea plants under kitazin stress and bio inoculated with $R$. leguminosarum RP1 strain. Here, SVI seedling vigor index, RL root length, SL shoot length, RFW root fresh weight, SFW shoot fresh weight, RDW root dry weight, SDW shoot dry weight, chl total chlorophyll, corot carotenoid content, NDB nodule biomass, LHb leghaemoglobin content, SY seed yield, GP grain protein, RN, root nitrogen, SN shoot nitrogen, RP root phosphorous, SP shoot phosphorous, R pro, root proline, S pro shoot proline, L pro leaf proline, G pro grain proline, APX ascorbate peroxidase, GPX guaiacol peroxidase, POD peroxidase, CAT catalase and MDA malondialdehyde. 
their interaction (bioinoculant $\times$ kitazin) were significant ( $p \leq$ 0.05). Morphologically, the structure and appearance of nodules developed on RP1 inoculated plants grown in presence of test fungicide was bigger, healthy and pink compared to plants grown in soils treated only with kitazin. The pink coloured nodules indicating formation of LHb was comparatively greater on RP1 bio-inoculated pea plants relative to only kitazin treated plants. The enhanced/improved symbiotic interaction resulting in massive nodulation on bio inoculated leguminous host developed under kitazin stressed environment is a strong and clear evidence of positive and effective microbial colonization and its persistence in fungicide contaminated soil which conclusively enhanced overall performance of peas even under stressed situations. Similar, enhancement in growth and yield of PGPR inoculated green gram plants raised under herbicides stressed soils has recently been reported by Shahid et al. ${ }^{54}$
3.7.4 Proline accumulation, lipid peroxidation and antioxidant enzymes. Proline, a distinctly water-soluble amino acid biomolecule is known to protect biological membranes from destructive impacts of higher concentrations of inorganics. Moreover, proline is reported to act as a - (i) protein-compatible hydro trope and (ii) hydroxyl radical scavenger. The increased level of these cellular proteins thus provides a protection to different plant species while growing under adverse (biotic and abiotic stresses) conditions. Keeping in mind strange features of stressor molecules, we also determined proline accumulated in different organs of pea plants. Here, we found considerable accumulation of proline in shoots, roots, foliage and grains of peas raised under kitazin stress. The quantity of proline accumulated in shoots, roots, and foliage (measured at $90 \mathrm{DAS}$ ) and grains (at 130 DAS) increased with cumulative doses of kitazin (Table 4). A maximum of $27.8 \pm 3.7,42.3 \pm 1.6$ and $12 \pm 1.0 \mu$ moles per $\mathrm{mg}$ fw proline was detected in shoots, roots and foliage of pea at $288 \mu \mathrm{g}$
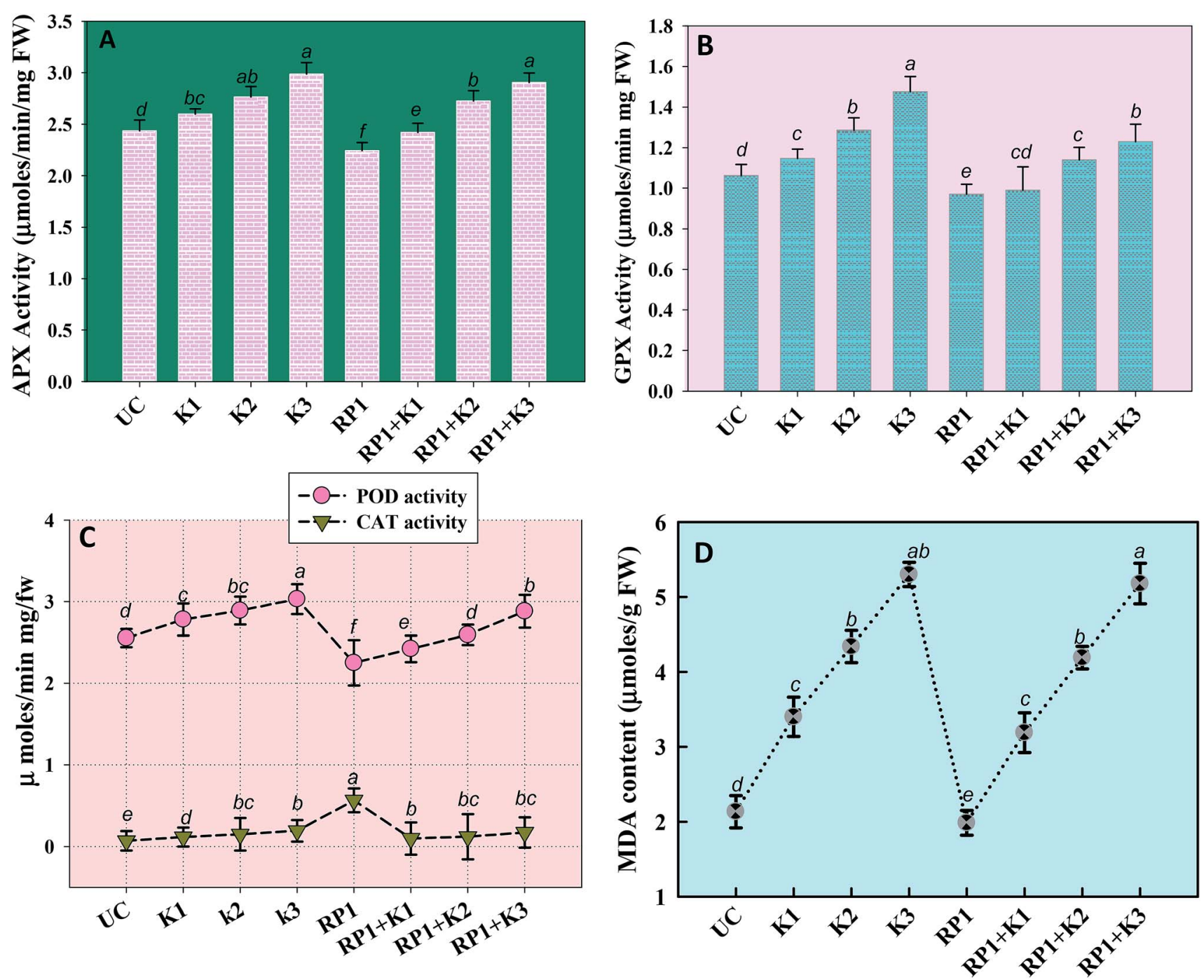

Fig. 8 Antioxidant enzyme activity and lipid peroxidation (malondialdehyde content) extracted from foliage of $P$. sativum plants grown in the presence of fungicide tolerant bacterial inoculant (strain RP1) and treated with varying concentrations of kitazin; APX activity (A), GPX activity (B), POD and CAT activity (C) and MDA content (D). Each value is a mean of three independent replicates $(n=3)$ where each replicate constituted three plants/pot. Mean values followed by different letters are significantly different at $p \leq 0.05$ according to DMRT test. Vertical and scattered bars represent means $\pm \mathrm{SD}(n=3)$. ANOVA significant at $p \leq 0.05$. 
$\mathrm{kg}^{-1}$ soil kitazin. Similarly, an increased level of proline content in Vicia faba raised in soils contaminated with herbicide fusillade has been reported..$^{55}$ But, in the presence of inoculum (strain RP1), increased levels of proline were noticeably reduced, and hence, $25.8 \pm 1.9(7 \%), 41.2 \pm 2.6(2.7 \%)$ and $10.6 \pm 1.5(36 \%) \mu$ moles per $\mathrm{mg}$ fw proline was recorded in shoots, roots and foliage, respectively at same rate of kitazin. $R$. leguminosarum strain RP1 significantly declined proline content in shoots, roots and foliage of pea plants by 8.8, 18 and $34 \%$ respectively, compared to plants developed in soils amended with only $192 \mu \mathrm{g} \mathrm{kg}{ }^{-1}$ kitazin (Table 4). The reduction in proline level in various plant organs of inoculated pea raised in kitazin contaminated soil could possibly be due to bioremediating/detoxification ability of bacterial strain RP1.
Similarly, a tolerant PGPR strain $P$. aeruginosa significantly reduced proline concentration in Cicer arietinum plants raised in soil contaminated with heavy metals. ${ }^{56}$

Malondialdehyde (MDA) is yet another important biomolecule which is often used as an index of lipid peroxidation under harsh environmental conditions. In present study, efficiency of kitazin in inducing lipid peroxidation and causing variations in antioxidants enzymes was assayed. In our study, lipid peroxidation level in pea plants gradually increased as kitazin concentration increased. The maximum quantity $(5.3 \mu$ moles per $\mathrm{g}$ fw) of MDA was detected in foliage of pea plants grown in soil treated with $288 \mu \mathrm{g} \mathrm{kg}^{-1}$ kitazin. Whereas, $R$. leguminosarum inoculated pea plant exhibited a marginal decline of 8.8, 3.5 and
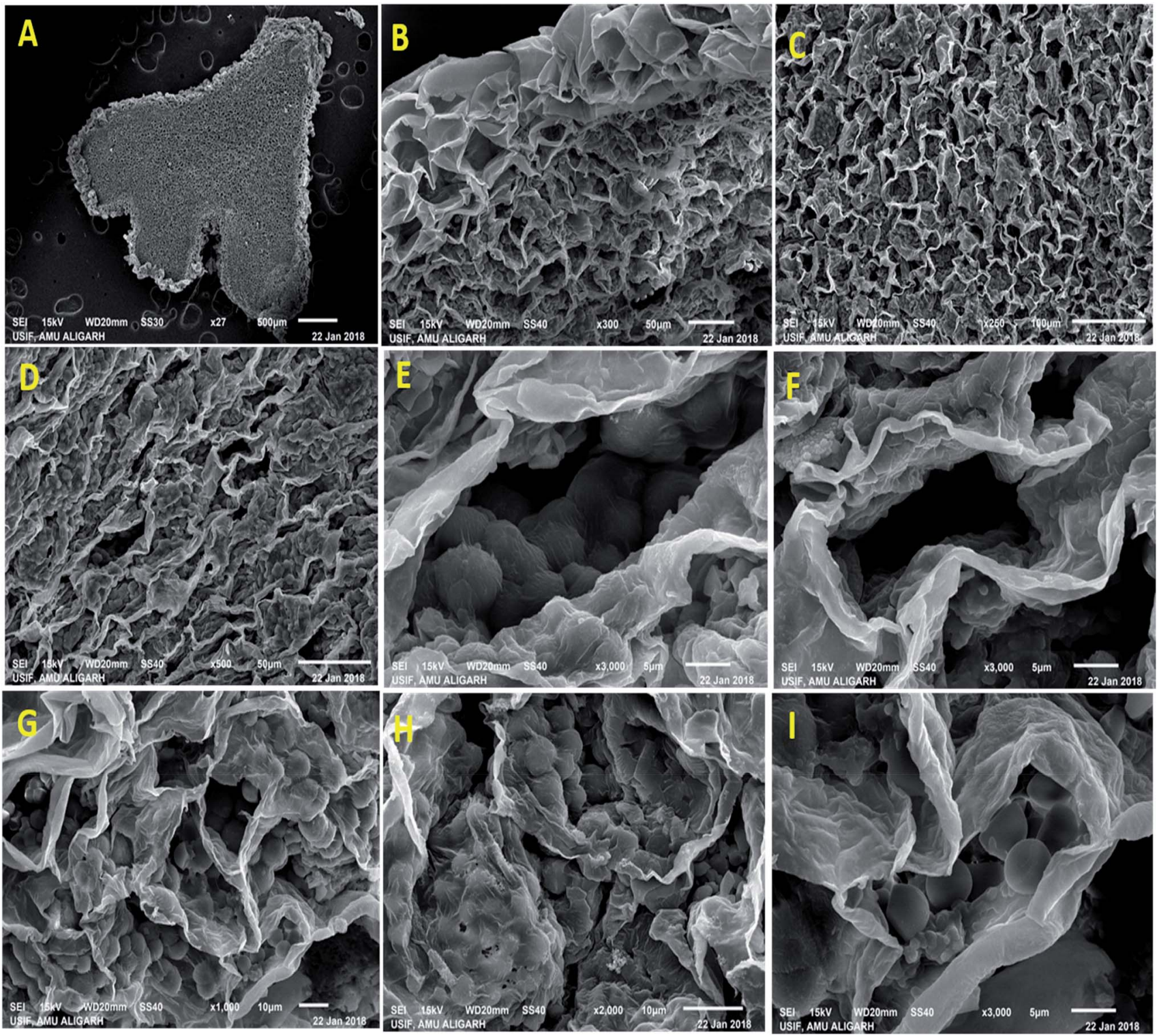

Fig. 9 A low magnification scanning electron micrograph of $P$. sativum nodules cut longitudinally through its long axis showing overall nodule structure. A portion of nodule scanned from inside to the surface showing (A) central tissue (B) cortex tissue (C) empty cortex tissue and (D) collapsed empty cortex tissue which make up the outermost surface layer of the nodule, (E) showing the structure of infected cells packed with healthy $Y$ and $T$ shaped bacteroides in untreated nodules and (F) depicts the empty cells representing the absences of bacteroids, and (G-I) displayed the infected cells containing deteriorating bacteroides with zoogloeal mass covered with the thin layers. 
$3.4 \%$ at 96,192 and $288 \mu \mathrm{g} \mathrm{kg}^{-1}$ of kitazin, respectively in MDA content (Fig. 8D). Similarly, B. cepacia strain PSBB1 in other study was found to decrease level of MDA content in glyphosate treated Cicer arietinum plants. ${ }^{57}$

Antioxidant defence enzymes like POD, CAT, GPX and APX extracted from tissues of foliage varied between bio-inoculated and uninoculated plants raised in kitazin contaminated soils. Normally, it was observed that level of antioxidant enzymes increased as the concentration of kitazin increased from $1 \times$ to $3 \times$ concentrations. In contrast $R$. leguminosarum strain RP1 declined POD activity extremely by $13 \%, 9.7 \%$ and $5 \%$ at 96,192 and $288 \mu \mathrm{g} \mathrm{kg}^{-1}$ of kitazin, respectively (Fig. 8). The CAT activity in pea plants treated with $288 \mu \mathrm{g} \mathrm{kg}^{-1}$ kitazin soil increased greatly by $36.6 \%$ related to uninoculated control, which however, was decreased by $11.7 \%$ by strain RP1. Furthermore, a maximum reduction of $13 \%$ in GPX level was observed in foliage of bio-inoculated pea plants raised with $96 \mu \mathrm{g} \mathrm{kg}^{-1}$ kitazin soil. The APX activity in foliage was increased maximally by $18 \%$ at $3 \times$ concentration of kitazin compared to un-inoculated control plants. On the contrary, $R$. leguminosarum RP1, instigated a maximum reduction of $6.8 \%$ in APX activity even in presence of $1 \times$ concentration of kitazin. In agreement to this study, activity of antioxidant defence enzyme such as CAT, GR, SOD and APX in leaf tissue of Cicer arietinum plants grown in stressed environment have been reported to increase expressively in a dose dependent manner. ${ }^{\mathbf{5 6}}$

\subsection{Cytological/anatomical deviations in pea nodules and localization of Rhizobium}

Nodule formation comprises of complex process that probably be interrupted by harmful environmental factors and these may be noticeable at cytological and anatomical level. Therefore, to understand the noxious effect of kitazin on Rhizobium-pea interaction on nodule morpho-anatomy, nodules were detached from the root system of plants raised in kitazin supplemented soil and inoculated with $R$. leguminosarum. SEM images revealed the presence of bacteroids surrounding the vacuoles. A dense enlarged and mass of bacteroids are seen in fungicides untreated (control) nodules, whereas, distorted/damaged, smaller and chaotic formed bacteroids were observed in kitazin supplemented nodules (Fig. 9). This may possibly be due to the toxicity of fungicide. Similarly, anatomical/ultrastructural changes in nodular tissues after exposing faba bean-Rhizobium leguminosarum coupling to silver nanoparticles has been reported. ${ }^{58}$ Nevertheless, despite reports here and there, to best of our knowledge, this is the first finding highlighting the destructive influence of fungicide (kitazin) on anatomy and ultrastructure of pea nodules inoculated with $R$. leguminosarum. These investigations further proved that eventhough the Rhizobium inoculant could eliminate the fungicide toxicity to certain extent but at higher doses this fungicide can obstruct the pea-Rhizobium symbiosis leading ultimately to obliteration in $\mathrm{N}$ supply to plants due to destructive effects on bacteroids.

\subsection{R. leguminosarum strain RP1 as a root colonizer}

Colonization is an important, initial and compulsory element of plant-microbe interaction in the rhizosphere for protecting the plants from various soil pathogens and for growth and development of plants. ${ }^{59}$ Many root colonizing symbiotic rhizobia have been used as a potent biofertilizers/bio-inoculants to induce the growth of plants. Considering these, $R$. leguminosarum strain RP1 was checked for its root colonizing ability using SEM and CLSM (Fig. 10). For this, bacterial inoculated roots of pea plants were washed thoroughly, fixed in glutaraldehyde and viewed under

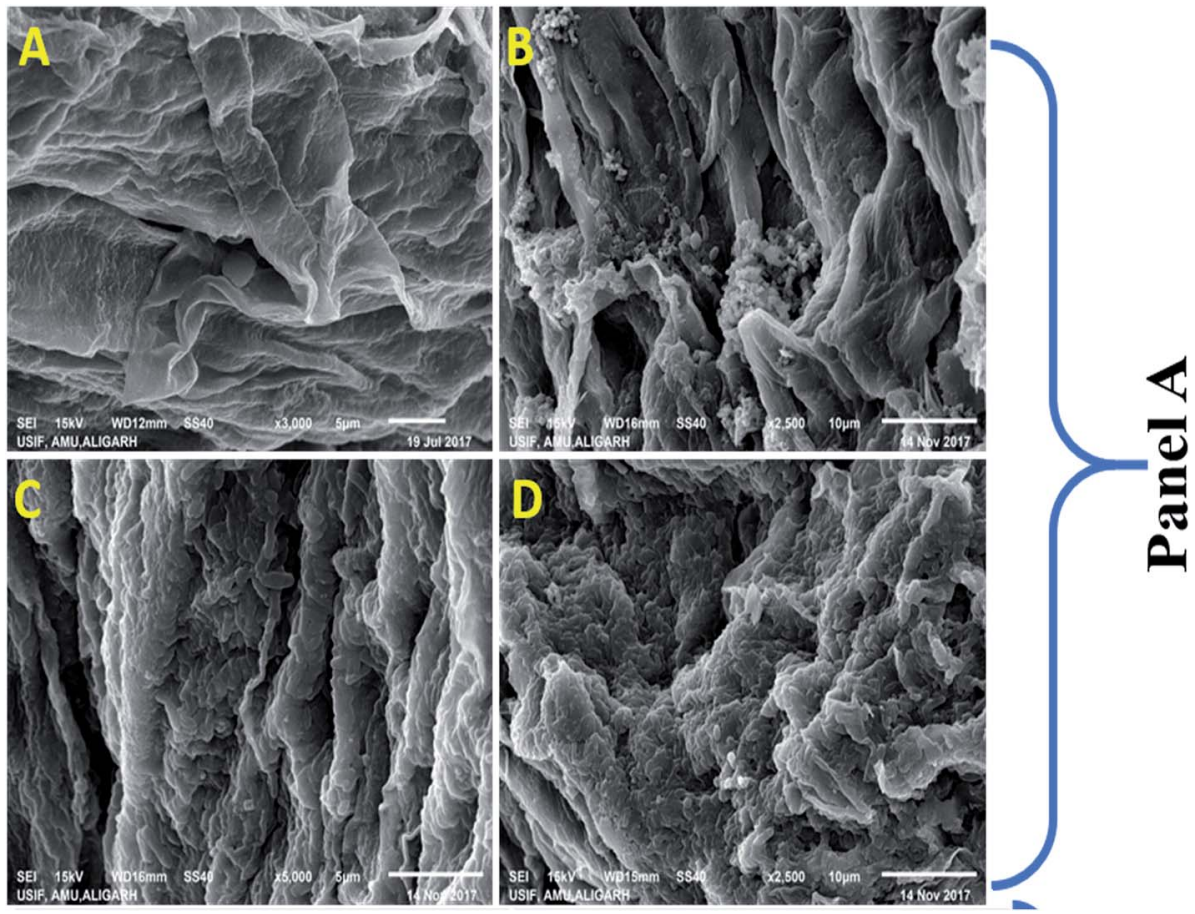

Fig. 10 Panel (A) represents the SEM image of colonization of $R$. leguminosarum on root surface of pea plants, respectively; in both the panel (A) shows the untreated control root surface, while, (B-D) depicts the attachments/colonization of bacterial cells on root surface. 
microscope. Microscopic observation revealed that cells were aggregated on root tips and at the elongation zone, whereas, uninoculated roots did not show any bacterial colonization. Several constituents of bacterial cell surface such as exopolysaccharides, cell wall polysaccharide and extra cellular bacterial proteins can support the process of attachment on root surface. As PGPR colonize the root surfaces, they multiply and reproduce by receiving key signalling compounds and nutrients from the root exudates which successively leads to biofilm formation on the root system and this is very clear indication of successful plant-microbe colonization. Similarly, successive colonization of root colonization and attachment of bacteria on root surface for the improved growth of leguminous plant has been reported. ${ }^{60}$

\section{Conclusion}

Phytotoxicity of kitazin to existence, morpho-structure, membrane disruption and growth regulators of $R$. leguminosarum varied greatly. Sadly, the ability of RP1 strain to produce bioactive molecules was altered at higher rates of fungicide, yet interestingly it was not abolished completely. Moreover, kitazin toxicity to peas was visible through reduction in germination, root tip distortion and oxidative damage in vitro bioassays. $R$. leguminosarum in plant assay experiment, protected peas from fungicidal toxicity and concurrently improved the biomass, symbiosis, chlorophyll formation, seed attributes and nutrients accumulation. Augmentation of pea production even under harsh condition by RP1 as observed in this study may probably be due to expression of numerous PGP factors, strong colonizing efficiency of this strain, and substantive reduction in stressor molecules and antioxidants in peas. Conclusively, fungicide tolerant ability together with growth enhancing activities and stress relieving potential makes strain RP1 as an interesting and agronomically viable and sustainable choice for enhancing pea production in soils contaminated even with fungicides.

\section{Conflicts of interest}

None.

\section{Abbreviations}

$\begin{array}{ll}\text { IAA } & \text { Indole acetic acid } \\ \text { EPS } & \text { Exopolysaccharides } \\ \text { SVI } & \text { Seedling vigor index } \\ \text { PL } & \text { Plant length } \\ \text { RL } & \text { Root length } \\ \text { POD } & \text { Peroxidase } \\ \text { APX } & \text { Ascorbate peroxidase } \\ \text { GPX } & \text { Guaiacol peroxidase } \\ \text { CAT } & \text { Catalase } \\ \text { MDA } & \text { Malondialdehyde }\end{array}$

\section{Acknowledgements}

The authors would like to thank Macrogen Seoul, Korea, for providing 16S rRNA gene Sequencing analysis, School of Advanced Sciences, Chemistry Division VIT University, Vellore, University Sophisticated Instrument facility (USIF) for providing SEM and CLSM facilities.

\section{References}

1 J. C. Rana, M. Rana, V. Sharma, A. Nag, R. K. Chahota and T. R. Sharma, Genetic Diversity and Structure of Pea (Pisum sativum L.) Germplasm Based on Morphological and SSR Markers, Plant Mol. Biol. Rep., 2017, 35(1), 118-129.

2 C. S. Jacobsen and M. H. Hjelmsø, Agricultural soils, pesticides and microbial diversity, Curr. Opin. Biotechnol., 2014, 27, 15-20.

3 B. Anuradha, A. Rekhapadmini and V. Rangaswamy, Influence of tebuconazole and copper hydroxide on phosphatase and urease activities in red sandy loam and black clay soils, 3 Biotech, 2016, 6, 78.

4 T. Uthman, A. Awosanya, A. Ayanwale and T. Ayinde, The effect of fungicides on the nodulation of cowpea (Vigna unguiculata L.) in a tropical rainforest, Environ. J. Sus. Dev., 2017, 7, 56-61.

5 Y. M. Xiao, L. Esser, F. Zhou, C. Li, Y. H. Zhou, C. A. Yu, Z. H. Qin and D. Xia, Studies on inhibition of respiratory cytochrome bc1 complex by the fungicide pyrimorph suggest a novel inhibitory mechanism, PLoS One, 2014, 9, 93765.

6 M. Shahid, A. Zaidi, M. S. Khan, A. Rizvi, S. Saif and B. Ahmed, Recent advances in management strategies of vegetable diseases, in Microbial strategies for vegetable production, Springer, Cham, 2017, pp. 197-226.

7 M. Shahid and M. S. Khan, Fungicide tolerant Bradyrhizobium japonicum mitigate toxicity and enhance greengram production under hexaconazole stress, $J$. Environ. Sci., 2019, 78, 92-108.

8 T. Roy, A. Bandopadhyay, P. J. Sonawane, S. Majumdar, N. R. Mahapatra, S. Alam and N. Das, Bio-effective disease control and plant growth promotion in lentil by two pesticide degrading strains of Bacillus sp, Biol. Control, 2018, 127, 55-63.

9 A. Zaidi, M. S. Khan, S. Saif, A. Rizvi, B. Ahmed and M. Shahid, Role of nitrogen-fixing plant growth-promoting rhizobacteria in sustainable production of vegetables: current perspective, in Microbial Strategies for Vegetable Production, Springer, Cham, 2017a, pp. 49-79.

10 A. Zaidi, M. S. Khan, A. Rizvi, S. Saif, B. Ahmad and M. Shahid, Role of phosphate-solubilizing bacteria in legume improvement, in Microbes for Legume Improvement, Springer, Cham, 2017b, pp. 175-197.

11 A. Rizvi, A. Zaidi, M. S. Khan, S. Saif, B. Ahmed and M. Shahid, Growth improvement and management of vegetable diseases by plant growth-promoting rhizobacteria, in Microbial Strategies for Vegetable Production, Springer, Cham, 2017, pp. 99-123. 
12 S. K. Narwal and R. Gupta, Biodegradation of xenobiotic compounds, Handbook of Research on Inventive Bioremediation Techniques, 2017, p. 186.

13 E. L. Imada, A. L. M. de Oliveira, M. Hungria and E. P. Rodrigues, Indole-3-acetic acid production via the indole-3-pyruvate pathway by plant growth promoter Rhizobium tropici CIAT 899 is strongly inhibited by ammonium, Res. Microbiol., 2017, 168(3), 283-292.

14 R. Sagolshemcha, Y. N. Devi and W. R. Singh, Plant growth promoting effect and biocontrol potential of Rhizobium spp. against Macrophomina phaseolina, Int. J. Curr. Microbiol. Appl. Sci., 2017, 6(6), 2695-2701.

15 P. K. Ghosh, T. K. De and T. K. Maiti, Role of ACC deaminase as a stress ameliorating enzyme of plant growth-promoting rhizobacteria useful in stress agriculture: a review, in Role of Rhizospheric Microbes in Soil 57-106), Springer, Singapore, 2018.

16 A. Zaidi, M. S. Khan, E. Ahmad, S. Saif, A. Rizvi and M. Shahid, Growth stimulation and management of diseases of ornamental plants using phosphate solubilizing microorganisms: current perspective, Acta Physiol. Plant., 2016, 38(5), 117.

17 S. Saif, M. S. Khan, A. Zaidi, A. Rizvi and M. Shahid, Metal toxicity to certain vegetables and bioremediation of metalpolluted soils, in Microbial Strategies for Vegetable Production, Springer, Cham, 2017, pp. 167-196.

18 B. Ahmed, A. Zaidi, M. S. Khan, A. Rizvi, S. Saif and M. Shahid, Perspectives of plant growth promoting rhizobacteria in growth enhancement and sustainable production of tomato, in Microbial Strategies for Vegetable Production, Springer, Cham, 2017, pp. 125-149.

19 G. J. Holt, N. R. Krieg and P. H. A. Sneath, Gram negative aerobic/microaerophilic rods and cocci, in Bergey's Manual of Determinative Bacteriology, Williams and Wilkins, Lippincott, Philadelphia, 9th edn, 1994.

20 J. M. Brick, R. M. Bostock and S. E. Silverstone, Rapid in situ assay for indole acetic acid production by bacteria immobilized on a nitrocellulose membrane, Appl. Environ. Microbiol., 1991, 57(2), 535-538.

21 A. W. Bakker and B. Schippers, Microbial cyanide production in the rhizosphere in relation to potato yield reduction and Pseudomonas sp.-mediated plant growthstimulation, Soil Biol. Biochem., 1987, 451-457.

22 D. W. Dye, The inadequacy of the usual determinative tests for the identification of Xanthomonas spp, N. Z. J. Sci., 1962, 5(4), 393-416.

23 M. L. Jackson, Soil Chemical Analysis, Prentice Hall, New Delhi India, 1976.

24 D. B. Alexander and D. A. Zuberer, Use of chrome azurol S reagents to evaluate siderophore production by rhizosphere bacteria, Biol. Fertil. Soils, 1991, 12(1), 39-45.

25 M. W. Reeves, L. Pine, J. B. Neilands and A. Balows, Absence of siderophore activity in Legionella species grown in irondeficient media, J. Bacteriol., 1983, 154(1), 324-329.

26 M. Dworkin and J. Foster, Experiments with some microorganisms which utilize ethane and hydrogen, $J$. Bacteriol., 1958, 75, 592-601.
27 S. Shah, J. Li, B. A. Moffatt and B. R. Glick, Isolation and characterization of ACC deaminase genes from two different plant growths promoting rhizobacteria, Can. J. Microbiol., 1998, 44, 833-843.

28 D. M. Penrose and B. R. Glick, Method for isolating and characterizing ACC deaminase containing plant growth promoting rhizobacteria, Physiol. Plant., 2003, 118, 10-15.

29 B. Ahmed, A. Hashmi, M. S. Khan and J. Musarrat, ROS mediated destruction of cell membrane, growth and biofilms of human bacterial pathogens by stable metallic Ag-NPs functionalized from bell pepper extract and quercetin, Adv. Powder Technol., 2018, 29(7), 1601-1616.

30 B. Ahmed, M. Shahid, M. S. Khan and J. Musarrat, Chromosomal aberrations, cell suppression and oxidative stress generation induced by metal oxide nanoparticles in onion (Allium cepa) bulb, Metallomics, 2018, 10(9), 13151327.

31 D. I. Arnon, Copper enzymes in isolated chloroplasts. Polyphenol oxidase in Beta vulgaris, Appl. Environ. Microbiol., 1949, 55, 1665-1669.

32 S. Sadasivum and A. Manickam, Biochemical Methods, New Age International Publishers (P) Ltd., New Delhi, 1992.

33 R. C. Lindner, Rapid analytical methods for some of the more common inorganic constituents of plant tissues, Plant Physiol., 1944, 19, 76.

34 O. H. Lowry, N. J. Rosebrough, A. L. Farr and R. J. Randall, Protein measurement with the Folin phenol reagent, $J$. Biol. Chem., 1951, 193, 265-275.

35 L. S. Bates, R. P. Woldren and I. D. Teare, Rapid determination of free proline for water stress studies, Plant Soil, 1973, 39, 205-208.

36 R. L. Heath and L. Packer, Photo peroxidation in isolated chloroplast. I. Kinetics and stoicheometry of fatty peroxidation, Arch. Biochem. Biophys., 1968, 125, 189-198.

37 R. F. Beer Jr and I. W. Sizer, A spectrophotometric method for measuring the breakdown of hydrogen peroxidase by catalase, J. Biol. Chem., 1952, 195, 133-140.

38 S. S. Leonard, G. K. Harris and X. Shi, Metal-induced oxidative stress and signal transduction, Free Radicals Biol. Med., 2004, 37, 1921-1942.

39 R. Hammerschmidt, E. M. Nuckles and J. Kuć, Association of enhanced peroxidase activity with induced systemic resistance of cucumber to Colletotrichum lagenarium, Physiol. Plant Pathol., 1982, 20(1), 73-76.

$40 \mathrm{~J}$. Zhang and M. B. Kirkham, Antioxidant responses to drought in sunflower and sorghum seedlings, New Phytol., 1996, 132, 361-373.

$41 \mathrm{M}$. Shahid and M. S. Khan, Cellular destruction, phytohormones and growth modulating enzymes production by Bacillus subtilis strain BC8 impacted by fungicides, Pestic. Biochem. Physiol., 2018, 149, 8-19.

42 J. P. Verma, D. K. Jaiswal and P. K. Maurya, Screening of bacterial strains for developing effective pesticide-tolerant plant growth-promoting microbial consortia from rhizosphere soils of vegetable fields of eastern Uttar Pradesh, India, Energy Ecology and Environment, 2016, 1(6), 408-418. 
43 P. Jha, J. Panwar and P. N. Jha, Mechanistic insights on plant root colonization by bacterial endophytes: a symbiotic relationship for sustainable agriculture, Environmental Sustainability, 2018, 1-14.

44 M. Shahid, A. Zaidi, A. Ehtram and M. S. Khan, In vitro investigation to explore the toxicity of different groups of pesticides for an agronomically important rhizosphere isolate Azotobacter vinelandii, Pestic. Biochem. Physiol., 2019, DOI: 10.1016/j.pestbp.2019.03.006.

45 P. Trapet, L. Avoscan, A. Klinguer, S. Pateyron, S. Citerne, C. Chervin, S. Mazurier, P. Lemanceau, D. Wendehenne and A. Besson-Bard, The Pseudomonas fluorescens siderophore pyoverdine weakens Arabidopsis thaliana defence in favour of growth in iron-deficient conditions, Plant Physiol., 2016, 01537.

46 A. A. Belimov, I. C. Dodd, V. I. Safronova, A. I. Shaposhnikov, T. S. Azarova, N. M. Makarova, W. J. Davies and I. A. Tikhonovich, Rhizobacteria that produce auxins and contain 1-amino-cyclopropane-1-carboxylic acid deaminase decrease amino acid concentrations in the rhizosphere and improve growth and yield of well-watered and waterlimited potato (Solanum tuberosum), Ann. Appl. Biol., 2015, 167(1), 11-25.

47 F. Jalili, K. Khavazi, E. Pazira, A. Nejati, H. A. Rahmani, H. R. Sadaghiani and M. Miransari, Isolation and characterization of ACC deaminase-producing fluorescent pseudomonads, to alleviate salinity stress on canola (Brassica napus L.) growth, J. Plant Physiol., 2009, 166(6), 667-674.

48 S. Saif and M. S. Khan, Assessment of heavy metals toxicity on plant growth promoting rhizobacteria and seedling characteristics of Pseudomonas putida SFB3 inoculated greengram, Act. Sci. Agric., 2017, 1, 47-56.

49 M. Shahid, B. Ahmed and M. S. Khan, Evaluation of microbiological management strategy of herbicide toxicity to greengram plants, Biocatal. Agric. Biotechnol., 2018, 14, 96-108.

50 G. Grossmann, M. Krebs, A. Maizel, Y. Stahl, J. E. Vermeer and T. Ott, Green light for quantitative live-cell imaging in plants, J. Cell Sci., 2018, 209270.
51 M. Asgher, M. I. R. Khan, N. A. Anjum and N. A. Khan, Minimising toxicity of cadmium in plants-role of plant growth regulators, Protoplasma, 2015, 252(2), 399-413.

52 D. R. Duca, D. R. Rose and B. R. Glick, Indole acetic acid overproduction transformants of the rhizobacterium Pseudomonas sp. UW4, Antonie Leeuwenhoek, 2018, 1-16.

53 M. Shahid and M. S. Khan, Assessment of glyphosate and quizalofop mediated toxicity to greengram [Vigna radiata (L.) Wilczek], stress abatement and growth promotion by herbicide tolerant Bradyrhizobium and Pseudomonas species, Int. J. Curr. Microbiol. Appl. Sci., 2017, 6(12), 30013016, DOI: 10.20546/ijcmas.2017.612.351.

54 M. Shahid, B. Ahmed, A. Zaidi and M. S. Khan, Toxicity of fungicides to Pisum sativum: a study of oxidative damage, growth suppression, cellular death and morphoanatomical changes, RSC Adv., 2018, 8(67), 38483-38498.

55 M. E. H. Osman, A. M. Abo-Shady and M. M. El-Nagar, Cyanobacterial Arthrospira (Spirulina platensis) as safener against harmful effects of fusilade herbicide on faba bean plant, R. Lin., 2016, 27(3), 455-462.

56 S. Saif and M. S. Khan, Assessment of toxic impact of metals on proline, antioxidant enzymes, and biological characteristics of Pseudomonas aeruginosa inoculated Cicer arietinum grown in chromium and nickel-stressed sandy clay loam soils, Environ. Monit. Assess., 2018, 190(5), 290.

57 M. Shahid and M. S. Khan, Glyphosate induced toxicity to chickpea plants and stress alleviation by herbicide tolerant phosphate solubilizing Burkholderia cepacia PSBB1 carrying multifarious plant growth promoting activities, 3 Biotech, 2018, 8(2), 131.

58 M. H. Abd-Alla, N. A. Nafady and D. M. Khalaf, Assessment of silver nanoparticles contamination on faba bean-Rhizobium leguminosarum bv. viciae-Glomus aggregatum symbiosis: implications for induction of autophagy process in root nodule, Agric., Ecosyst. Environ., 2016, 218, 163-177.

59 A. Verma, S. Kumar, G. Kumar, J. K. Saini, R. Agrawal, A. Satlewal and M. W. Ansari, Rhizosphere metabolite profiling: An opportunity to understand plant-microbe interactions for crop improvement, in Crop Improvement Through Microbial Biotechnology, 2018, pp. 343-361.

60 R. M. Wheatley and P. S. Poole, Mechanisms of bacterial attachment to roots, FEMS Microbiol. Rev., 2018, 448-461. 